\title{
A BUSCA POR UMA DECISÃO JUDICIAL CONSTITUCIONALMENTE ADEQUADA E A NECESSIDADE DE SUBJUGAÇÃO DA JURISPRUDÊNCIA DOS VALORES AVILTADORA DOS (PRÉ)COMPROMISSOS
}

\author{
Suélen Farenzena*
}

\begin{abstract}
Resumo
O presente texto tem por objetivo analisar a problemática atinente a degradação dos (pré) compromissos - tomando como pano de fundo a Jurisprudência dos Valores - ocasionada pelo apego do direito ao paradigma da subjetividade, visando, com isso, efetuar uma crítica à discricionariedade e ao arbítrio, defendendo a fundamentação das decisões judiciais como garantia de manutenção de um Estado Democrático de Direito.O estudo propõe-se a demonstrar que, ignorando-se o contexto histórico em que a Jurisprudência dos Valores fora desenvolvida, é a mesma trazida ao Brasil, passando a ser amplamente utilizada de forma acrítica, evidenciando, em conseqüência, a importância de superação da concepçãoiluminista assujeitadora - típica do esquema sujeito-objeto - e a relevância da assimilação pelo direito da evolução da filosofia. Evidencia, por fim, que decisões constitucionalmente adequadas devem levar em conta a questão datradição, da coerência e da integridade e o direito da parte de compreender os motivos que levaram o julgador a decidir contra ou a seu favor.
\end{abstract}

Palavras-chave

Jurisprudência dos Valores. Degradação dos (Pré)Compromissos. Decisão Constitucionalmente Adequada.

\section{Abstract}

This paper aims to analyze the problem regards the degradation of (pre) commitments taking as background the Court of Values - caused by the attachment of the right to the paradigm of subjectivity, in order thereby to make a critique of discretion and will, defending the reasoning of judicial decisions as a means to maintain a democratic state. The study proposes to demonstrate that ignoring the historical context in which the Court of Values was developed, it is brought to Brazil, becoming widely used uncritically, showing, as a result, the importance of overcoming Enlightenment conception assujeitadora - typical subject-object schema - and the relevance of assimilation by the law of development of philosophy. Evidence, finally, that constitutionally adequate decisions must take into account the issue of tradition, consistency and integrity and the right part of understanding the motives which led the judge to decide for or against your favor.

Mestranda e Bolsista em Direito Público pela UNISINOS/RS, vinculada à Linha de Pesquisa Sociedade, Novos Direitos e Transnacionalização. Advogada e Professora Universitária. 


\section{Keywords}

Jurisprudence of Values. Degradation of (pre) commitments. Suitable Constitutionally decision.

\section{INTRODUÇÃO}

O presente texto tem por escopo analisar a problemática atinente a degradação dos (pré)compromissos ocasionada pelo apego do direito ao paradigma da subjetividade - cavalo de Tróia da modernidade -, visando, com isso, efetuar uma crítica à discricionariedade e ao arbítrio, defendendo a fundamentação das decisões judiciais como garantia de manutenção de um Estado Democrático de Direito.

Para isso, inicialmente, contextualiza-se que, em países de modernidade tardia como o Brasil, é comum a importação (às vezes até mesmo parcialmente) de teorias criadas por juristas de outras nações, em outros períodos históricos, para outras necessidades de soluções, como é o exemplo da Jurisprudência dos Valores (1).Sucede que, com a queda das doutrinas oficiais ligadas às ditaduras derrotadas, na Alemanha e na Itália, a tese de aceitação do direito que vinha do Estado, qualquer que fosse seu conteúdo, já não podia ser aceita, motivo pelo qual passaram a ser elaboradas teorias que, embora não prevendo uma criação imediata do direito por parte do juiz, lhe reservavam uma tarefa criativa no delimitado âmbito das normas jurídicas positivas, mas estendido para além de tais normas com a ajuda de máximas da experiência e de princípios gerais, sendo, porquanto, razoável apontar a mesma como umadas matrizes responsáveis por difundir a crença da importância (sic) do exercício interpretativo que levanta o véu que encobre a resposta que a regra não pode dar.

Busca-se, então, evidenciar uma verdadeira importância, qual seja, de superação daconcepção iluminista assujeitadora - responsável pela degradação dos (Pré)Compromissos e o caráter antidemocrático de aplicação do Direito - e a relevância da assimilação pelo direito da evolução da filosofia (2). O fato é que, com a passagem da Filosofia Hermenêutica para a Hermenêutica Filosófica, a compreensão se dá como evento no momento em que há uma interação entre o mundo daquilo que se conhece e o mundo daquele que se propõe a conhecer, havendo, por isso, uma interação circular entre passado e presente, que leva a fusão dos momentos de compreensão, interpretação e aplicação, vistos pela velha tradição hermenêutica como atividades distintas.

Defendendo a fundamentação das decisões judiciais como garantia de manutenção de um Estado Democrático de Direito, demonstra-se, por fim, que decisões constitucionalmente adequadas devem levar em conta a questão datradição, da coerência e da integridade e o direito da parte de compreender os motivos que levaram o julgador a decidir contra ou a seu favor(3). A resposta correta, assim, evita decisões ad hoc,representando uma blindagem contra interpretações deslegitimadoras e despistadoras do conteúdoque sustenta o domínio normativo dos textos constitucionais. 


\section{A JURISPRUDÊNCIA DOS VALORES E SUA IMPORTAÇÃO E UTILIZAÇÃO ACRÍTICA}

Com a queda das doutrinas oficiais ligadas às ditaduras derrotadas, na Alemanha e na Itália, os teóricos do direito tiveram de remeter-se às doutrinas pré-bélicas para iniciar a reconstrução de uma teoria jurídica que acompanhasse e favorecesse o renascimento dos Estados Democráticos. Porém, exatamente às doutrinas pré-bélicas podia-se censurar, no mínimo, o fato de não terem oposto nenhuma barreira à afirmação das ditaduras. $\mathrm{O}$ positivismo jurídico, que havia caracterizado as primeiras décadas do século XX, pregara a aceitação do direito que vinha do Estado, qualquer que fosse seu conteúdo. A tese da indiferença do conteúdo do direito positivo já não podia ser aceita. ${ }^{1}$ Com isso, a elaboração européia ocidental, mesmo não podendo receber por inteiro o modelo do Common $\mathrm{Law}^{2}$, começou a elaborar teorias que, embora não prevendo uma criação imediata do direito por parte do juiz, lhe reservavam uma tarefa criativa no delimitado âmbito das normas jurídicas positivas, mas estendido para além de tais normas com a ajuda de máximas da experiência e de princípios gerais.

A jurisprudência dos interesses conseguiu, pelo menos no âmbito privado, um inusitado êxito. Ressentia-se, todavia, da aplicação equívoca da expressão interesses, ora empregada como fator causal da motivação do legislador, ora como objeto das valorações por ele empreendidas e, por vezes mesmo, como critério de valoração. Passou-se a sublinhar que seria necessário que o conceito de interesse fosse delimitado às representações da pretensão que as partes num litígio têm ou devem ter, quando se empenham na obtenção de efeitos jurídicos favoráveis e, distinguir assim, de modo rigoroso, o conceito de interesse dos critérios legais de valoração. Estes não seriam em si propriamente interesses, mas corolários da idéia de justiça, inferidos pelo legislador desse fim último. Sucede que a jurisprudência está na sua essência, mediante a aplicação das valorações legais, nos antípodas de uma valoração autônoma (do juiz). As leis são, de acordo com esta concepção, pelo menos no âmbito do direito privado, instrumentos de regulação de conflitos de interesses previsíveis e típicos entre particulares ou grupos sociais, de tal modo que um interesse tenha de ceder a outro na exata medida em que este possa prevalecer. Esta prevalência consubstancia uma valoração, para a qual o legislador pode ser determinado pelos mais diversos motivos. O mesmo, para além de valorar interesses individuais ou de grupo, tem também certamente em conta pontos de vista de ordenação, exigências do tráfego, a necessidade de segurança jurídica. O modo como valora

1 LOSANO, Mario G. Sistema e Estrutura do Direito: o século XX. Trad. Luca Lamberti. Vol. 2. São Paulo: Martins Fontes, 2010, p. 244-5.

2 Seu fundamento não era a norma geral e abstrata, mas o precedente jurisprudencial, ao qual se acompanhava uma equity que levava em conta as particularidades do caso em exame, e que, portanto - segundo um áureo ditado - variava de acordo com a dimensão do pé do chanceler chamado a aplicá-la. Para o realismo americano - que teve como célebre representante Oliver W. Holmes - o direito se extrai da análise das sentenças. Graças a essa análise pode-se razoavelmente (não mais, assim, racionalmente) estabelecer como se comportarão os juízes no futuro (LOSANO, Mario G. Sistema e Estrutura do Direito: o século XX. Trad. Luca Lamberti. Vol. 2. São Paulo: Martins Fontes, 2010, p. 144). 
esses distintos interesses e necessidades nos respectivos nexos de regulação e como confere prevalência a qualquer um deles plasma-se na regulação por ele encontrada e decorre desta, bem como, das manifestações dos participantes no processo legislativo. As valorações do legislador assim identificadas permitem extrair resultados, quer para a interpretação da lei, quer como, em certas circunstâncias, para a resolução de casos por ele não diretamente regulados ${ }^{3}$, mas a tratar analogamente a luz de critérios de valoração.

Em outras palavras, para a jurisprudência dos interesses, o juiz deveria verificar a vontade originária do legislador, e sua avaliação pessoal inserir-se-ia apenas se aquela primeira verificação não tivesse sido frutuosa. Porém, aquela teoria não indicava com que método o interprete poderia continuar sua atividade se não conseguisse verificar o interesse do legislador. Ao contrário, a jurisprudência dos valores constata que o juiz está sempre obrigado a prolatar uma sentença (proibição do déni de justice) e se propõe indicar os valores que o guiam, quando a norma positiva silencia. Por isso, a jurisprudência dos valores completa, mas não substitui, a jurisprudência dos interesses ${ }^{4}$ - quando as normas são excessivamente imprecisas, então a teoria indica quais valores podem ser aplicados em conformidade com o ordenamento jurídico.

A jurisprudência dos interesses, com efeito, deslocara o centro da pesquisa dos conceitos abstratos ${ }^{5}$ para a realidade social. Philipp Heck,analisando a postura que deveria ser adotada pelos juízes quando da decisão judicial nos casos concretos, assentou que o juiz não deve se limitar a preencher as normas em branco que a lei contenha. Tem também de completar e eventualmente

3 LARENZ, Karl. Metodologia da Ciência do Direito. Trad. José Lamego. $33^{\mathbf{a}}$ ed. Lisboa: Fundação Calouste Gulbenkian, 1997, p. 163-4.

4 LOSANO, Mario G. Sistema e Estrutura do Direito: o século XX. Trad. Luca Lamberti. Vol. 2. São Paulo: Martins Fontes, 2010, p. 243.

5 A Jurisprudência dos Conceitos consistiu em uma corrente de pensamento jus-filosófico que apresentou a idéia de direito como um sistema conceitual em forma de pirâmide. Desenvolveuse entre o jusnaturalismo, com quem tentou romper, e o positivismo, em quem encontrou a sua gênese.Georg Friedrich Puchta, considerado o pai da Jurisprudência dos Conceitos, pois foi quem primeiro defendeu a idéia de direito como uma ciência de conceitos. Discípulo e sucessor de Savigny na Universidade de Berlim foi influenciado pelo idealismo alemão. Tal como seu mestre, desenvolveu a idéia de Direito como um sistema. Mas, diferentemente daquele, para quem o sistema se apresenta na forma de organismo (todos os elementos constitutivos gravitando em torno de um centro), Puchta propôs um sistema lógico e hierarquicamente organizado na forma de uma pirâmide, a chamada pirâmide de conceitos.O conceito supremo é o conceito dotado de maior abstração (a priori o conceito Kantiano de liberdade) e seu conteúdo determina o conteúdo de todos os outros, de modo que todas as proposições jurídicas se extraem do próprio sistema, devendo observar-se a experiência histórica da comunidade, o "espírito do povo" (o que demonstra a influência de Savigny em seu pensamento). Essa corrente considerava, nesse desiderato, ser possível, a partir da recombinação dos conceitos obtidos pela análise jurídica, construir novos conceitos, "trazendo à consciência e à luz do dia proposições jurídicas que, ocultas no espírito do direito nacional, não se tinham ainda exprimido, nem na imediata convicção e na atuação dos elementos do povo, nem nos ditames da própria lei escrita, que patentemente só se vêm a revelar enquanto produto de uma dedução da ciência"(LARENZ, Karl. Metodologia da Ciência do Direito. Trad. José Lamego. 3ํㅡㄹ ed. Lisboa: Fundação Calouste Gulbenkian, 1997, p. 24 e 22 ). 
corrigir, em conformidade com os interesses, os comandos exis-tentes. O juiz não é simples aparelho de subsunção em que por um lado entram a hipótese de fato e a norma jurídica e de onde saia, pelo outro lado, a sentença, sem qualquer valoração pessoal. É também, pelo contrário, criador das normas a aplicar e auxiliar, portanto, do legis-lador, embora subordinado. ${ }^{6} \mathrm{O}$ resultado da decisão judicial e, conseqüentemente, a proteção dos interesses determinantes da lei, depende essencialmente da forma como o juiz a interpreta, dizia ele.Com isso, deixava confusa com a noção de interesse com critérios valorativos.

Com Westermann, entretanto, toma corpo claramente uma primeira linha demarcatória entre normas e valores: por um lado, os interesses; por outro, os critérios valorativos da lei. O mesmo parte da construção de que eles são valorações do legislador, traduzidas em norma e, portanto, vinculantes. Exemplificando esses valores como a tutela do menor ou da propriedade, afirma que são deduções da idéia de justiça, realizadas pelo legislador e incluídas numa norma do direito positivo, para na seqüência delinear que, se esses valores não transparecem claramente da norma, o juiz pode recorrer aos princípios que orientam um setor legislativo inteiro; se, depois, também essa via resulta impraticável, pode remontar aos princípios ainda mais gerais, inferidos da Constituição. Além dos princípios que derivam diretamente de um setor jurídico preciso ou da Constituição, ele não reconhece outras fontes valorativas, contudo, que possam vincular o juiz. ${ }^{7}$ Para ele, os valores extrajurídicos existem, mas não são juridicamente vinculantes.

Em Larenz, por seu turno, chegou-se à ligação imediata entre direito e valor, indicando-se uma linha contínua ao longo da qual o juiz se move livremente. Para ele, é manifesto que ao juiz não é possível em muitos casos fazer decorrer a decisão apenas da lei, nem sequer das valorações do legislador que lhe incumbe conhecer. Este é, desde logo, o caso em que a lei lança mão dos denominados conceitos indeterminados ou de cláusulas gerais. O presentese evidenciacomo um quadro muito mais geral que o juiz, no caso concreto, terá de preencher mediante uma valoração adicional. É aqui o juiz, portanto, remetido para a sua intuição valorativa, para a sua capacidade de julgar, sedimentada no exercício da sua atividade (o seu reto juízo) ou existem valores e critérios de valoração extra ou supralegais a que ele possa e deva arrimar-se? ${ }^{8}$

6 HECK, Philipp. Interpretação das Leis e Jurisprudência dos Interesses. Trad. José Osório. São Paulo: Saraiva, 1947, p. 23-4.

7 O horizonte valorativo de Westermann é, portanto, coincidente com o do direito positivo. Por isso, a posição de Westermann foi definida como uma jurisprudência dos valores imanentes à lei: para ela, de fato, o jurista não pode estar vinculado a valores não presentes no direito positivo (LOSANO, Mario G. Sistema e Estrutura do Direito: o século XX. Trad. Luca Lamberti. Vol. 2. São Paulo: Martins Fontes, 2010, p. 253-4).

8 Tal acontece, ressalta o mesmo, igualmente nos casos em que o julgador depara-se com novas questões relativamente às quais não pôde ainda o legislador tomar posição, ou quando desapareceram os pressupostos de que partiu o legislador para efetuar a sua valoração, ou quando normas e regulações colidem entre si, sem ser possível descortinar a qual atribuiria o legislador prevalência em casos idênticos àquele que o juiz tem perante si (LARENZ, Karl. Metodologia da Ciência do Direito. Trad. 
Indo mais além,Larenz reconhece que o problema complica-se diante dos inúmeros casos em que previamente se acreditara que a mera subsunção da situação de fato à previsão normativa seria suficiente, só que o que na verdade acontece, diz ele, é que acaba sendo necessária uma ordenação valorativa ou um juízo de valor para qualificar a situação de fato de determinado modo, em consonância com o indicado pela previsão normativa, circunstância que ocasiona um problema, posto que prepondera ainda na ciência a idéia de que os valores são um ato de opção pessoal, não passíveis de uma fundamentação racional. Nesta linha de pensamento, afirma o autor, chega-se inevitavelmente à conclusão de que em inúmeros casos (e não apenas em alguns casos de fronteira) subentra no lugar da valoração do legislador a valoração pessoal do juiz, a qual se subtrai a comprovação de acordo com um critério objetivo. Assim sendo, tal significaria que uma comprovação de grande número de decisões de acordo com métodos científicos só seria acessível para a ciência do direito de um modo limitado e que essa não estaria em ampla medida apta a prestar qualquer auxílio ao juiz na conformação dos juízos de valor que lhe são requeridos.

Formulando, pois, a proposta de um método para trabalhar com (eliminar) essas lacunas, o mesmo especifica que os três instrumentos para preenchê-las (a analogia, a redução teleológica e a extensão teleológica) não devem limitar-se as intenções e as decisões tomadas conscientemente pelo legislador, mas devem compreender também finalidades jurídicas objetivas e princípios válidos para o ordenamento jurídico inteiro.O direito é assim entendido como um conjunto coerente em cujo interior pode-se, porém, ir além do direito positivo, ou seja, além do direito estatuído segundo os procedimentos constitucionais.Nesses três casos, o juiz se move fora do direito positivo e deduz seus princípios do mundo dos valores. Assim sendo, mais do que às normas jurídicas, Larenz se remete à consciência jurídica, por isso de sua concepção receber a nomenclatura de uma jurisprudência dos valores praeter legem, mas intra ius. ${ }^{9}$

Nesse contexto, para Larenz o problema dos valores torna-se parte integrante da determinação do conceito de direito: o direito é submetido às exigências da justiça.A justiça não é nem a norma fundamental do ordenamento, nem o axioma do qual deduzir outras normas, mas um ideal que o direito positivo tenta realizar, conseguindo-o apenas em parte. Existem, por isso, partes do direito positivo que não estão conformes o ideal de justiça e, portanto, não são vinculantes.Na interpretação da norma a ser aplicada, o juiz deve procurar qual valor de justiça perseguiu o legislador, valor que deve refletir, de modo exemplar, a consciência jurídica do tempo. Logo, não é de todo possível ao juiz, na maioria dos casos, chegar à decisão estritamente com base na lei, e, porque esta carece de interpretação e a interpretação é mais ou menos discricionária ou requer dele a emissão de um juízo de valor, subsiste a questão de se saber

José Lamego. 3ae ed. Lisboa: Fundação Calouste Gulbenkian, 1997, p. 164-5).

9 LOSANO, Mario G. Sistema e Estrutura do Direito: o século XX. Trad. Luca Lamberti. Vol. 2. São Paulo: Martins Fontes, 2010, p. 256-7. 
o que é que realmente motivou o juiz na sua decisão ${ }^{10}$ - ou seja, no lugar da ciência normativa do direito, que comprove como deva ele decidir, subentra uma ciência fatual, uma psicologia ou uma sociologia judiciárias.

No entanto, enquanto Larenz se remete à consciência jurídica (ou seja, ao sentido individual da justiça), Josef Esser procura na realidade social os valores com os quais completar o ordenamento jurídico. Influenciado pelo realismo anglo-americano, Esser chega a uma construção que aceita o sistema tradicional, mas faz com que seja acompanhado por uma referência aos valores ínsitos nos princípios que podem ser extraídos das sentenças. O fato é que em Benjamin Cardozo $^{11}$, estudioso americano que Esser se remete explicitamente para explicar os princípios presentes no ordenamento jurídico, o direito é constituído por rules, com base nas quais são decididos cada um dos casos, e por principles, que estão na base dessas rules.

Com apoio no desenvolvimento da doutrina da culpa in contrahendo ${ }^{12}$, Esser, nesse diapasão,para além da referencia à natureza das coisas ou de uma determinada instituição, ou seja, a um sentido do ser inscrito nas próprias relações humanas e alcançável, pelo menos fragmentariamente, remete para as zonas pré-positivas dos princípios ético-jurídicos e da convicção geral. Os princípios formam-se, primeiro, inconscientemente, num longo processo subterrâneo, até que por fim a descoberta, a inventio de uma idéia até então desprovida de forma encontra de súbito uma formulação convincente e que não mais se confunde com a mera interpretação e construção do que já existe no direito positivo. À sentença judicial, especialmente à pratica jurisprudencial constante, cabe, então, o papel de funcionar como um transformador dos prin-

${ }^{10}$ LARENZ, Karl. Metodologia da Ciência do Direito. Trad. José Lamego. 3ạ ed. Lisboa: Fundação Calouste Gulbenkian, 1997, p. 166.

${ }_{11}$ Atuando nos principais cargos da magistratura estadual e federal, até chegar a Suprema Corte dos EUA em 1932, o jurista sempre revelou em suas decisões uma preocupação com o contexto social e econômico dos casos, transferindo para a prática suas convicções teóricas a respeito da justiça. Foi ele, por exemplo, um dos principais responsáveis pela legitimação que permitiu implantar o New Deal, e que havia sido inicialmente rejeitada pela maioria da corte. Cardozo foi, assim, um dos principais representantes da teoria sociológica do direito por fundar sua compreensão do mesmo na relação necessária entre as normas da lei e a vida social por elas regulada. Para ele, o direito possui um vínculo necessário com os contextos histórico, econômico e social, que condicionam a elaboração e, sobretudo, a aplicação da lei. A subsunção lógica é apenas o início da atividade judicial, não seu termo. Na decisão a ser proferida, a aplicação da norma deve ser mediada pelas motivações de conveniência social, afirmava (GIUSTI, Ernesto. Cardozo, Nathan Benjamin. In: BARRETTO, Vicente de Paulo (Coord.). Dicionário de Filosofia do Direito. São Leopoldo: UNISINOS, 2009, p. 119).

${ }^{12}$ Há um determinado problema de fundo que obriga a elaborar uma solução; esta, a princípio, obtém-se de forma puramente casuística, sem pesquisa nem demonstração de princípios; procura-se depois um apoio, em termos pragmáticos, para a solução encontrada, recorrendo a esta ou àquela fonte legal apropriada; só quando as contradições sistemáticas se tornam impossíveis de disfarçar é que se confessa que as fontes foram utilizadas como simples pontos de apoio sistemático para um princípio jurídico cujo alcance é muito mais vasto (LARENZ, Karl. Metodologia da Ciência do Direito. Trad. José Lamego. $3^{\text {a }}$ ed. Lisboa: Fundação Calouste Gulbenkian, 1997, p. 191-2). 
cípios pré-positivos em proposições e instituições jurídicas positivas.

Para Cardozo, nesse enfoque, entre rules e principles existe uma relação de influência recíproca: de fato, as rules se deduzem dos principles; porém, quandotambém estes últimos se tornam estéreis, os juízes resolvem os casos concretos segundo novos critérios e, das sentenças assim emanadas, é possível remontar a novos princípios. Esse ordenamento jurídico composto de rules e principles é, pois, um embrião de sistema jurídico no qual é evidente a função criativa do juiz, como de resto é inevitável numa teoria jurídica de Common Law. Esser descreve uma estrutura análoga composta de normas e de princípios jurídicos, mas, visto que se move num ambiente de direito continental, a ligação entre o mundo dos princípios e as normas deve passar através de um elemento legislativo, que para Esser é constituído pelas cláusulas gerais. Para ele, elas permitem atualizar e fazer evoluir cada uma das normas mediante uma referência aos princípios que estão por trás das cláusulas gerais. Assim, embora vinculado às normas jurídicas, como todo jurista continental, Esser vai além delas, graças à função evolutiva e criativa que concede às cláusulas gerais, reconhecendo, com isso, o valor da construção dogmática tradicional, mas afirmando a exigência de a ela associar uma consideração dos valores que permita expandir o direito positivo. ${ }^{13}$

Não obstante, ignorando-se o contexto histórico em que essa teoria fora criada, é a mesma trazida ao Brasil, passando a ser amplamente utilizada de forma acrítica. Streck, nesse sentido, faz uma crítica pontual a respeito, ao analisar a decisão acerca das uniões homoafetivas, que demonstra uma espécie de retorno (tardio) a jurisprudência dos valores. O mesmo alerta em sua narrativa que há uma perigosa tendência no interior da comunidade jurídica de recorrer aos tribunais para sanar eventuais omissões do legislador, pugnando, em verdade, por um verdadeiro exercício de jurisprudência dos valores.Só que, o que passa aos olhos da maioria, é que a (in)segurança jurídica mostra-se ofendida, por exemplo, não por deixar sem regulamentação legal a convivência entre pessoas do mesmo sexo, mas sim no momento em que a Corte altera, a pretexto de um "esquecimento do constituinte", de uma "descoberta valorativa", oudo saneamento (incorreto) de uma "inconstitucionalidade da própria Constituição", o texto da Carta Magna, como se poder constituinte fosse, gerando, com isso, um mal-estar institucional gravíssimo.Trata-se, pois, como adverte o autor, de um sintoma de repristinação da jurisprudência dos valores. ${ }^{14} \mathrm{~A}$ despeito do texto da Constituição propiciar um tecido normativo "fechado" demais, setores do direito pensam que é preciso "abrir" esse sentido da normatividade constitucional, usando aleatória e descompromissada-mente, para tal, dos princípios constitucionais.

${ }^{13}$ LOSANO, Mario G. Sistema e Estrutura do Direito: o século XX. Trad. Luca Lamberti. Vol. 2. São Paulo: Martins Fontes, 2010, p. 260-1.

${ }^{14}$ STRECK; Lenio Luiz; BARRETTO, Vicente de Paulo; OLIVEIRA, Rafael Tomaz de. Ulisses e o canto das sereias: sobre ativismos judiciais e os perigos da instauração de um"terceiro turno da constituinte". Revista de Estudos Constitucionais, Hermenêutica e Teoria do Direito, v. 1, n. 2, julho/dezembro 2009, p. 80. 
A adoção da ponderação de valorescomo opção metodológica para fundamentação de decisões tem sido uma constante no Brasil ${ }^{15}$. A fim de superar o dito positivismo e seus métodos arcaicos de interpretação, osórgãos julgadores vêm, de maneira acrítica, importando uma doutrina alemã que já há muito é alvo de severas objeções. $O$ fato é que a mesma, com base na teoria de Alexy, postula que regras são normas que ordenam, proíbem ou permitem algo definitivamente ou autorizam. Logo, quando os seus pressupostos estão cumpridos, produz-se a conseqüência jurídica. Se não se quer aceitar esta, deve ou declarar-se a regra como inválida e, com isso, despedi-la do ordenamento jurídico, ou, então, inserir-se uma exceção na regra e, nesse sentido, criar uma nova regra. ${ }^{16} \mathrm{~A}$ forma da aplicação da regra é, pois, a da subsunção. Princípios contêm, pelo contrário, um dever ideal. Eles são mandamentos a serem otimizados. A forma de aplicação para eles típica é, por isso, a ponderação ${ }^{17}$. Com

${ }^{15}$ Veja-se, ilustrativamente: (i) APELAÇÃO CÍVEL. UNIÃO ESTÁVEL. GUARDA E ALIMENTOS À FILHA MENOR. ACORDO HOMOLOGADO EM AUDIÊNCIA. EXCEPCIONALIDADE DO CASO QUE AUTORIZA O CONHECIMENTO DO RECURSO E DESCONSTITUIÇÃO DA SENTENÇA. PONDE-RAÇÃO DE VALORES. 1. Em audiência, presentes as partes, estando apenas o autor acompanhado de procurador e ausente o representante do Ministério Público, foi homologado acordo pelo qual se estabeleceu a livre visitação e alimentos para a menina de tenra idade no valor equivalente a 50\% da mensalidade da escolhinha. 2. Excepcionalmente, em face das circunstâncias do caso - considerando o preponderante interesse da criança (art. 227 da $\mathrm{CF}$ ), que foi violado com a homologação de acordo que lhe é flagrantemente nocivo -, é de conhecer da apelação. 3. Pela especial circunstância de estar em conflito direito indisponível de menor (alimentos e visitas) se impõe a desconstituição da sentença, uma vez que a livre visitação é de todo incompatível com a eficácia da medida protetiva de afastamento do varão do lar e proibição de se aproximar da recorrente, bem como os alimentos, nos moldes como fixados, sem previsão de dia e modo de pagamento ou de forma de reajuste, ferem direito da criança. Conheceram da apelação e desconstituíram a sentença. Unânime (70044090843 RS, Relator: Luiz Felipe Brasil Santos, Data de Julgamento: 15/09/2011, Oitava Câmara Cível, Data de Publicação: Diário da Justiça do dia 21/09/2011); (ii) HABEAS CORPUS. PROCESSO PENAL. APELAÇÃOO. TRIBUNAL REGIONAL FEDERAL.JULGAMENTO REALIZADO POR TURMA COMPOSTA MAJORITARIAMENTE POR JUÍZES FEDERAIS CONVOCADOS. NULIDADE. INEXIS-TÊNCIA. INOCORRÊNCIA DE OFENSAAO PRINCÍPIO DO JUIZ NATURAL. PONDERAÇÃO DE VALORES. ORDEM DENEGADA. 1. O Pleno do Supremo Tribunal Federal, nos autos do HC no 96.821/SP (Relator o Ministro Ricardo Lewandowski, DJe de 25/6/2010), consagrou orientação no sentido de que não há ofensa aos princípios do juiz natural ou do duplo grau de jurisdição na apreciação de recursos por órgão composto majoritariamente por juízes de primeiro grau convocados. Tal compreensão foi ratificada recentemente no bojo do Recurso Extraordinário no 597.133/RS, também de Relatoria do Ministro Ricardo Lewandowski, em situação análoga à dos autos, por envolver a convocação de juízes federais para atuação nos Tribunais Regionais Federais. HC no 96.821/SP. 2. Ademais, especificamente no caso da Justiça Federal, há expressa previsão legal para a convocação de juízes de primeiro grau para atuarem em função de auxílio nos Tribunais Regionais Federais, nos termos do art. $4^{\circ}$ da Lei no 9.788/99, além da permissão contida na Lei Orgânica da Magistratura, em seu art. 118, não havendo, portanto, que se cogitar de constrangimento ilegal. 3. Habeas corpus denegado (149335 GO 2009/0192743-9, Relator: Ministro HAROLDO RODRIGUES - Desembargador convocado do TJ/CE, Data de Julgamento: 14/06/2011, T6 - SEXTA TURMA, Data de Publicação: DJe 28/06/2011).

${ }^{16}$ ALEXY, Robert. Constitucionalismo Discursivo. 2a ed. Porto Alegre: Livraria do Advogado, 2008, p. 37.

17 Por mais paradoxal que possa parecer, os princípios têm a finalidade de impedir "múltiplas respostas". Portanto, os princípios "fecham" a interpretação e não a "abrem", como sustentam, em especial, os adeptos das teorias da argumentação, por entenderem que, entre regras e princípios, 
efeito,comparando direitos a valores, tal doutrina coloca em cheque o próprio conceito de direito, o que nos leva a uma reflexão sobre os limites da atuação do Poder Judiciário no Estado Democrático de Direito.

Para Canaris, pois, a abertura do sistema significa a incompletude e aprovisoriedade do conhecimento científico. De fato,o jurista, como qualquer cientista, deve estar semprepreparado para pôr em causa o sistema até entãoelaborado e para o alargar ou modificar, com basenuma melhor consideração. Cada sistema científico é,assim, tão só um projeto de sistema, que apenasexprime o estado dos conhecimentos do seu tempo;por isso, necessariamente, ele não é nem definitivonem fechado, enquanto, no domínio em causa, umareelaboração científica e um progresso forem possíveis. ${ }^{18} \mathrm{Em}$ conseqüência, registra o autor, nunca podem ser tarefas dosistema o fixar a ciência ou o desenvolvimentodo direito num determinado Estado, mas antes, apenas,o exprimir o quadro geral de todos os reconhecimentosdo tempo, o garantir a sua concatenação entresi e, em especial, o facilitar a determinação dos efeitosreflexos que uma modificação (do conhecimento oudo objeto), num determinado ponto, tenha noutro,por força da regra da conseqüência interior.

Por sua vez, Kaufmanntrabalha com a idéia de que a incompletude da lei não é, ao contrário do que sugere a concepção positivista, uma falha; ela é aprorística e necessária. A lei não pode nem deve ser formulada de modo inequívoco, visto ser concebida para casos cuja diversidade é infinita. Uma lei fechada sobre si mesma, completa, sem lacunas, inequívoca, se tal fosse possível, faria estagnar a evolução do direito.Com isso em mente, ele questiona:como se pode subsumir num conceito tão extraordinariamente vago como repulsivo (ou então pense-se em subsunções em face de elementos tais como lei moral objetiva, bons costumes, sentido de decência de todos os espíritos justos, opinião dominante), isto é, encontrar esta ou aquela solução correta, de um modo estritamente dedutivo, mediante um simples silogismo lógico, sem qualquer valoração por parte dos juízes? Não influirá aqui também a concepção pessoal dos valores dos juízes, não terão eles, na decisão de casos destes (e de muitos outros semelhantes) sequer uma pré-compreensão ${ }^{19}$, alguma sensibilidade ju-

existe um grau menor ou maior de subjetividade do intérprete. A partir disso é possível dizer que é equivocada a tese de que os princípios são mandados de otimização e de que as regras traduzem especificidades (onde, em caso de colisão, uma afastaria a outra, na base do "tudo ou nada"). Ora, pensar assim é fazer uma concessão à discricionariedade.Não parece democrático delegar ao juiz o uso da ponderação para a "escolha" do princípio que será utilizado para a resolução do problema (STRECK, Lenio Luiz. Verdade e Consenso: Constituição, Hermenêutica e Teorias Discursivas - da possibilidade à necessidade de respostas corretas em Direito. $3^{\underline{a}}$ ed. Rio de Janeiro: Lumen Juris, 2009, p. 166-7).

18 CANARIS, Claus-Wilhelm. Pensamento Sistemático e Conceito de Sistema na Ciência do Direito. Trad. A. Menezes Cordeiro. Lisboa: Fundação Calouste Gulbenkian, 1989, p. 106.

19 Essa pré-compreensão é produto da relação intersubjetiva (sujeito-sujeito) que o intérprete tem no mundo. O intérprete não interpreta do alto de uma relação sujeito-objetivo. Estará, sim, sempre inserido em uma situação hermenêutica. Há uma "situação lingüística", não sendo a linguagem algo que esteja à disposição do intérprete, circunstância que inexoravelmente transformaria a atividade de interpretar em um ato voluntarista. Ao contrário disso, o intérprete "pertence" a 
rídica? Éóbvio que a têm, e isso nem é de censurar, pontua o autor. Merecedor de censura é, sim, o fato de eles não refletirem a sua pré-compreensão, o seu juízo de valor, a sua sensibilidade jurídica, apontando, por isso, fundamentações aparentes da sentença ${ }^{20}$; censurável é o fato de não argumentarem com clareza, antes proferindo um ato de autoridade/poder.

Lamego, de tal modo,considera que foi nessa época em que se deu a "perda das certezas jurídicas", referindo-se ao fato da criação de instrumentos metodológicos que propiciaram a "abertura" da estrita legalidade que sempre imperou em território germânico. Nessa medida, enuncia que foram criados e redefinidos institutos como as "cláusulas gerais", os "conceitos jurídicos indeterminados", as "normas em branco" eos chamados "princípios constitucionais". Por isso ele vai dizer quenão será exagerado afirmar que, muitas vezes, o recurso a argumentos holísticos, como todo de sentido ou ordem de valores, não se traduz noutra coisa senão no fazer passar de contrabando pontos de vista valorativos subjetivos, usurpando o sentido dos textos legais. É necessário contrariar tais exageros interpretativos ou hermenêuticos, adverte o mesmo, sob pena, de se dissolver o rule of $L_{a w}{ }^{21}$ e se converter as discussões jurisprudenciais em diretas querelas ideológicas.

É, no entanto, exatamente a jurisprudência da valoração que será duramente criticada também por Habermas, que a enquadrará como uma postura do Poder Judiciário que coloniza o espaço público e impede a tomada de decisões pela via democrática. Dirá que princípios ou normas mais elevadas, em cuja luz outras normas podem ser justificadas, possuem um sentido deontológico, ao passo que os valores têm um sentido teleológico. Por esses motivos, Habermasconclui que a transformação conceitual de direitos fundamentais em bens fundamentais significa que direitos foram mascarados pela teleologia, escondendo o fato de que em um contexto de justificação, normas e valores têm diferentes papéis na lógica da argumentação ${ }^{22}$.Em última instância, pontua o autor, apenas direitos podem ser invocados em um jogo argumentativo, eis

essa lingüisticidade. Ele é refém da linguagem. Nesse sentido, a atividade hermenêutica exsurge desse processo de (auto)compreensão (STRECK, Lenio Luiz. Hermenêutica (jurídica): compreendemos porque interpretamos ou interpretamos porque compreendemos? Uma resposta a partir do Ontological Turn. In: ROCHA, Leonel Severo; STRECK, Lenio Luiz (Org.). Anuário do Programa de Pós-Graduação em Direito. São Leopoldo: UNISINOS, 2003, p. 237).

${ }^{20}$ KAUFMANN, Arthur; HASSEMER, Winfried (Org.). Introdução à Filosofia do Direito e à Teoria do Direito Contemporâneas. Trad. Marcos Keel e Manuel Seca de Oliveira. Lisboa: Fundação Calouste Gulbenkian, 2002, p. 193 e 184.

${ }^{21}$ LAMEGO, José. Hermenêutica e Jurisprudência: análise de uma recepção. Lisboa: Fragmentos, 1990, p. 80.

${ }^{22}$ Normas e princípios, em virtude do seu caráter deontológico, podem pretender ser universalmente obrigatórios e não apenas especialmente preferíveis, já que eles possuem uma maior força de justificação que os valores, que, ao contrário, devem ser postos em uma ordem transitiva com outros valores, caso a caso e, como não há padrões racionais para isso, esse sobpesamento acontece arbitrariamente ou sem maior reflexão, de acordo com os padrões e hierarquias costumeiras (HABERMAS, Jürgen. Between facts and norms: contributions to a discourse theory of law and democracy. Cambridge: MIT, 1996, p. 259-61). 
que um julgamento orientado por princípios precisa decidir qual pretensão e qual ação em um dado conflito é correta e não como ponderar interesses ou rela-cionar valores. A validade jurídica do julgamento tem, assim, o caráter deontológico de um comando, e não o caráter teleológico de um bem que nós podemos alcançar até certo nível.

Eis o problema: a escolha do conceito de mundo vivido, além de ser feita a partir do campo da fenomenologia transcendental - portanto, da filosofia da consciência - e além de ser uma escolha de um fundamento de uma teoria representacional, é um conceito convertido por Habermas em um discurso apenas pragmático-empírico. Esse é, pois, o ponto que prende seu discurso ao velho paradigma - mundo vivido, mesmo redesenhado com sofisticadas tintas lingüísticas, continua sendo uma espécie de fundamentum, um senso comum ideal(izado) ${ }^{23}$, com funções contrafatuais.

Portanto, como adverte Streck, é razoável apontar para a jurisprudência dos valores e o positivismo normativista Kelseniano como as matrizes que colocaram na vontade o lócus do fundamentum. Na insuficiência daquela parte da linguagem para fornecer as respostas, chama-se à colação a subjetividade do intérprete ${ }^{24}$, que, de forma solipsista, levanta o véu que encobre a resposta que a regra não pode dar.

\section{A DEGRADAÇÃO DOS (PRÉ)COMPROMISSOSE O CARÁTER ANTIDEMOCRÁTICO DE APLICAÇÃO DO DIREITO}

Como então podemos seguir um caminho para encontrar mandamentos concretos em uma Constituição que de forma tão sublime nos oferece vagas advertências? Existem sinceras controvérsias sobre a forma como a Constituição deve ser lida, e, certamente, a razão para isso não é o fato de os debatedores terem acesso a diferentes fontes de informação. Eles tem a sua frente exatamente o mesmo texto, e tal texto tem apenas um história, embora complexa e multifacetada. Mas, naturalmente, pessoas diferentes acreditam em coisas diferentes a respeito de como essa história veio à luz, por meio da interpretação constitucional. Entretanto, o fato de se admitir essa percepção faz surgir uma questão óbvia: qual a relevância destas visões, premissas e convicções para a definição do modo como aquele texto tão bem resumido deverá ser lido? Será que a leitura do texto é justamente um pretexto para expressar a majestosa visão do leitor sobre os sagrados termos da lei constitucional? Será que a Constituição é simplesmente um espelho por meio do qual é possível enxergar aquilo que

${ }^{23}$ STRECK, Lenio Luiz. Verdade e Consenso: Constituição, Hermenêutica e Teorias Discursivas da possibilidade à necessidade de respostas corretas em Direito. $3^{3}$ ed. Rio de Janeiro: Lumen Juris, 2009, p. 38-9.

${ }^{24}$ STRECK, Lenio Luiz. Hermenêutica Jurídica (e)m Crise: uma exploração hermenêutica da construção do Direito. Porto Alegre: Livraria do Advogado, 2011, p. 145. 
se tem vontade? ${ }^{25}$

Muito juristas, inseridos no imaginário engendrado pela dogmática jurídica de cariz positivista-formalista, ainda acreditam que interpretar é desvendar o "sentido unívoco da norma", que interpretar é descobrir o "sentido e o alcance da norma", sendo tarefa precípua do intérprete procurar a significação correta dos conceitos jurídicos, ou que interpretar é buscar o "verdadeiro sentido da norma", ou ainda, que interpretar é "retirar da norma tudo o que nela contém" ${ }^{26}$ Como elenca Streck,acredita-se ainda que é possível descobrir a "vontade da norma" e que o legislador possui um espírito.

É verdade, pois, que na prática jurídica norte-americana, os juízes referem-se constantemente às múltiplas declarações feitas pelos membros do Congresso e por outros legisladores, nos relatórios das comissões ou nos debates formais, a respeito da finalidade de uma lei. Os juízes justificam que essas afirmações, vistas em conjunto formam, a história legislativa da lei, às quais devem respeitar. Podemos, contudo, adotar dois pontos de vista muito diferentes sobre essa prática de submeter-se à história legislativa. Um deles é o de Hércules. Ele aborda as múltiplas declarações feitas pelos legisladores no processo de elaboração da lei como atos políticos aos quais sua interpretação da lei deve ajustar-se e poder explicar, assim como precisa ajustar-se ao próprio texto da lei e explicá-lo. ${ }^{27} \mathrm{O}$ outro é o ponto de vista pressuposto pela objeção descrita, que trata essas declarações não como eventos importantes em si, mas como evidência do estado mental dos legisladores particulares que as fizeram, e que se presume ser representativas do estado de espírito da maioria dos legisladores $^{28}$ cujos votos criaram a lei.

Trabalhando com situações-problema, Dworkin questiona: o estado de espírito de quais pessoas serviu para fixar a intenção que subjaz à Lei das Espécies Ameaçadas? Seria o dos membros do Congresso que a promulgaram,

25 TRIBE, Laurence; DORF, Michael. Hermenêutica Constitucional. Trad. Amarílis de Souza Birchal. Belo Horizonte: Del Rey, 2007, p. 02-3.

26 STRECK, Lenio Luiz. Da Interpretação de Textos à Concretização de Direitos: a incindibilidade entre interpretar e aplicar a partir da diferença ontológica (ontologische differentz) entre texto e norma. In: COPETTI, André; STRECK, Lenio Luiz; ROCHA, Leonel Severo (Org.). Constituição, Sistemas Sociais e Hermenêutica. São Leopoldo: UNISINOS, 2005, p. 172.

27 DWORKIN, Ronald. O Império do Direito.Trad. Jeferson Luiz Camargo. São Paulo: Martins Fontes, 1999, p. 378-9.

${ }^{28}$ Hermes, que é quase tão arguto quanto Hercules e igualmente tão paciente, e também aceita o direito como integridade, assim como aceita a teoria da intenção do locutor na legislação, desde o início, está consciente de uma dificuldade nessa teoria. É bastante difícil descobrir as intenções de amigos e colegas, de adversários e amantes. De que modo ele pode ter esperanças de descobrir as intenções de estranhos pertencentes a uma outra época, que podem estar todos mortos? Como pode ter certeza de que havia quaisquer intenções proveitosas a serem descoberta? Os governantes de Nova York que adotaram a lei sobre testamentos talvez nunca tenham previsto o caso de um herdeiro assassino; é bem possível que muitos senadores e congressistas nunca tenham pensado no problema de pequenos peixes e barragens quase terminadas (DWORKIN, Ronald. O Império do Direito.Trad. Jeferson Luiz Camargo. São Paulo: Martins Fontes, 1999, p. 382). 
inclusive daqueles que votaram contra? Seriam as idéias de alguns - por exemplo, daqueles que falaram, ou falaram com mais freqüência nos debates - mais importantes que as idéias de outros? Que dizer dos funcionários e auxiliares administrativos que prepararam o projeto e o transformaram em lei? Será que suas intenções não têm mais valor que a de qualquer senador em particular? E o que dizer dos simples cidadãos que escreveram cartas a seus congressistas, prometeram ou ameaçaram votar a favor ou contra eles, fazer ou negar-se a fazer contribuições de campanha, dependendo do modo como eles votassem? E quanto aos vários lobbies e grupos de ação que desempenharam seu papel, atualmente considerado normal? Qualquer visão realista do processo legislativo inclui a influência desses grupos. Será, indo mais além, que sedeveriam levar em consideração as intenções dos vários legisladores que poderiam ter revogado a lei no decurso de anos e décadas, mas não o fizeram?

Esses mistérios, analisa o autor, são criados pela hipótese dominante de que as soluções devem convergir para o momento particular da históriaem que nasce a lei. Só que essa hipótese tem intrínseca a seqüela de que, à medida que o tempo passa, a lei deve se aplicada em outras circunstancias e, aí, os juízes se vêem diante de uma opção entre aplicar a lei original, com o significado que sempre teve, ou emendá-la às ocultas para atualizá-la. Esse é o dilema queas antigas leis apresentam ${ }^{29}$ - postula-se que os juízes devem escolher entre a mão morta, porém legítima, do passado e o encanto, claramente ilícito, do progresso.

O que preocupa neste tipo de argumento de tutela judicial é que ele traz consigo - de modo subterrâneo - uma idéia que tem ganhadoterreno e aceitação por parte da dogmática jurídica nacional: a necessidade de se recorrer a "bons ativismos judiciais" para resolverquestões que a sociedade em constante evolução acarreta e que os meios políticos de decisão (mormente o legislativo) não conseguemacompanhar ${ }^{30}$.

Sucede que os parlamentos têm demonstrado o caráter fantasioso da sua pretensão de se erigirem em instrumentos onipotentes do progresso social. Demasiadas leis foram emanadas demasiadamente tarde, ou bem cedo se tornaram totalmente obsoletas; muitas se revelaram ineficazes, quando não contraprodutivas, em relação às finalidades sociais que pretendiam atingir; e muitas, ainda, criaram confusão, obscuridade e descrédito da lei. Não se pode esquecer, ademais, que os parlamentos, nas sociedades pluralísticas, compõem-se na maior parte de políticos eleitos localmente, ou vinculados eleitoralmente a certas categorias ou grupos. Assim, os valores e prioridades desses políticos são, por isso, muito amiúde valores e prioridades locais, corporativos ou de

${ }^{29}$ DWORKIN, Ronald. O Império do Direito.Trad. Jeferson Luiz Camargo. São Paulo: Martins Fontes, 1999, p. 383 e 416.

30 STRECK; Lenio Luiz; BARRETTO, Vicente de Paulo; OLIVEIRA, Rafael Tomaz de. Ulisses e o canto das sereias: sobre ativismos judiciais e os perigos da instauração de um "terceiro turno da constituinte". Revista de Estudos Constitucionais, Hermenêutica e Teoria do Direito, v. 1, n. 2, julho/dezembro 2009, p. 77. 
grupo. Por isso, o declínio da confiança nos parlamentos constitui fenômeno que se apresenta com diversos sentidos e gravidade em muitos países. ${ }^{31} \mathrm{Em}$ certa medida, constitui elemento característico de todo mundo ocidental.

Os tribunais judiciais mostraram-se, em sua generalidade, relutantes em assumir essas novas e pesadas responsabilidades. Mas, a dura realidade da história moderna logo demonstrou que os tribunais, confrontados pelo gigantismo estatal do legislativo e do administrativo, não poderia fugir de uma inflexível alternativa: a) permanecer fiel, com pertinácia, à concepção tradicional, tipicamente do século XIX, dos limites da função jurisdicional; ou b) elevar-se ao nível dos outros poderes, tornar-se enfim o terceiro gigante ${ }^{32}$, capaz de controlar o legislador mastodonte e o leviatanesco administrador.

Dizendo que diverso é o modo dos dois procedimentos de formação do direito - legislativo e judiciário - o autor, entretanto, refere que,o bom juiz, bem pode ser criativo, dinâmico e ativista e, como tal, manifestar-se; no entanto, apenas o juiz ruim agiria com as formas e as modalidades do legislador, pois, se assim agisse, deixaria simplesmente de ser juiz. Mais adiante, atento à crítica de que isso não teria o condão de preservar o caráter democrático ${ }^{33}$, defende quese dissipou em grande parte a utopia tipicamente ocidental, concernente à perfeita capacidade dos poderes "políticos" de alcançar o consenso dos governados, ou pelo menos da sua maioria. Os cientistas políticos amplamente demonstraram, argumenta, que mesmo no melhor dos mundos possíveis, a liderança legislativa e executiva, embora tradicionalmente considerada "diretamente responsável perante o povo", nunca constituiu, diferentemente do judiciário, perfeito paradigma de democracia representativa.

Sucede, contudo, que não há como determinar a "bondade" ou a "maldade" de um determinado ativismojudicial.O mais correto é dizer que questões

31 Problemas, não menos sérios, também se fizeram (e se fazem) presentes no âmbito administrativo:o perigo de abusos por parte da burocracia, a ameaça da situação de tutela paternalística, quando não de opressão autoritária, sobre os cidadãos por parte do onipresente aparelho administrativo e, por isso, ao mesmo tempo distante, inacessível e não orientado para o seu serviço, o sentimento de impotência e abandono que termina por invadir todos os cidadãos incapazes, ou sem vontade, de se reunirem em grupos poderosos, com condições de obter acesso às inumeráveis alavancas da máquina burocrática, exercitando pressões sobre ela, a abulia e o anonimato, enfim, da grande maioria dos que também tiveram aquela capacidade ou vontade, por meio da qual uniram-se à massa dos participantes de tais grupos poderosos de pressão (CAPPELLETTI, Mauro. Juízes Legisladores? Trad. Carlos Alberto Alvaro de Oliveira. Porto Alegre: Sérgio Antonio Fabris, 1999, p. 44-5).

${ }^{32}$ CAPPELLETTI, Mauro. Juízes Legisladores? Trad. Carlos Alberto Alvaro de Oliveira. Porto Alegre: Sérgio Antonio Fabris, 1999, p. 46-7.

${ }_{33}$ No sentido de que é grande a tentação de reconhecer o Judiciário como uma elite capaz de se desviar dos trechos demasiadamente embaraçados da estrada do processo democrático, a qual tratar-se-ia, contudo, de desviação só aparentemente provisória; em realidade, seria ela a entrada de uma via incapaz de se reunir à estrada principal, conduzindo inevitavelmente, por mais longo e tortuoso que seja o caminho, ao estado totalitário (CAPPELLETTI, Mauro. Juízes Legisladores? Trad. Carlos Alberto Alvaro de Oliveira. Porto Alegre: Sérgio Antonio Fabris, 1999, p. 74 e 93-4). 
como essa não devem ser deixadas para serem resolvidas pela"vontade de poder" (Wille zur Macht) do Poder Judiciário. Delegar tais questões ao Judiciário é correr um sério risco: o de fragilizar aprodução democrática do direito, cerne da democracia. Ou vamos admitir que o direito - produzido democraticamente possa vir a sercorrigido por argumentações teleológicas ${ }^{34}$-fáticas-e/ou-morais?

O ponto de vista de Hércules não exige tal estrutura. Ele entende a idéia do propósito ou da intenção de uma lei não como uma combinação dos propósitos ou intenções de legisladores particulares, mas como o resultado da integridade, de adotar uma atitude interpretativa com relação aos eventos políticos que incluem a aprovação da lei. Ele anota as declarações que os legisladores fizeram no processo de aprová-la, mas trata-as como eventos políticos importantes em si próprios, não como evidência de qualquer estado de espírito por detrás delas. Assim, não tem nenhuma necessidade de precisar pontos de vista sobre o estado de espírito dos legisladores, ou que estados de espírito são esses, ou como ele fundira todos em um superestado de espírito da própria lei ${ }^{35}$. Tampouco supõe um momento canônico de discurso para o qual sua pesquisa histórica se dirige; a história que ele interpreta começa antes que a lei seja aprovada e continua até o momento em que deve decidir o que ela agora declara.

Ocorre que as teorias da autoridade jurídica (e quaisquer teorias concomitantes de interpretação) geralmente são adquiridas por atacado, não no varejo. A questão não é a respeito da autoridade ou da interpretação desta ou daquela lei, mas a respeito da relação entre autoridade e interpretação em geral. Devemos perguntar, então, se existe algo verdadeiro, de modo geral, acerca da maneira como as leis são produzidas, que torne o recurso às intenções dos legisladores uma estratégia de interpretação adequada. O modo como respondemos a essa questão dependerá, pois, do que consideramos ser o modelo geral mais útil do processo legislativo, no que diz respeito às teorias da autoridade. ${ }^{36} \mathrm{Nesse}$ nível, sugere o autor, será melhor evitarmos qualquer modelo que considere a legislação como, mais comumente, o produto intencional de um único autor-legislador.

Hércules $^{37}$, não obstante, respeita a integridade do texto legal, de modo

${ }^{34}$ STRECK; Lenio Luiz; BARRETTO, Vicente de Paulo; OLIVEIRA, Rafael Tomaz de. Ulisses e o canto das sereias: sobre ativismos judiciais e os perigos da instauração de um "terceiro turno da constituinte". Revista de Estudos Constitucionais, Hermenêutica e Teoria do Direito, v. 1, n. 2, julho/dezembro 2009, p. 78.

35 DWORKIN, Ronald. O Império do Direito.Trad. Jeferson Luiz Camargo. São Paulo: Martins Fontes, 1999, p. 380.

36 WALDRON, Jeremy. As intenções dos legisladores e a legislação não-intencional. In: MARMOR, Andrei (Org). Direito e Interpretação: ensaios de filosofia do direito. Trad. Luís Carlos Borges. São Paulo: Martins Fontes, 2000, p. 499.

${ }^{37}$ Para ilustrar de que modo um juiz filósofo poderia desenvolver, nos casos apropriados, teorias sobre aquilo que a intenção legislativa e os princípios jurídicos requerem, Dworkin concebe um jurista de capacidade, sabedoria, paciência e sagacidade, a quem chama de Hércules, supondo que Hércules seja juiz de alguma jurisdição norte-americana representativa. Nessa concepção, Hércules aceitaria que a lei tem o poder geral de criar e extinguir direitos jurídicos, e que o juiz tem o dever geral de seguir as decisões anteriores de seu tribunal ou dos tribunais superiores 
que não irá pensar que aprimora uma lei só por projetar nela suas próprias convicções; respeita a equidade política, por isso não irá ignorar totalmente a opinião pública tal como esta se revela e exprime nas declarações ligadas ao processo legislativo. Hércules interpreta, assim, a história em movimento, porque o relato que ele deve tornar tão bom quanto possível é o relato inteiro através de sua decisão e para além dela. Logo, não emenda leis antiquadas para adaptar-se a novos tempos, como sugeriria a metafísica da intenção do locutor. ${ }^{38}$ Reconhece em que se transformaram as velhas leis desde então.

O fato é que nos dias correntes, a palavra democracia domina com tal força alinguagem política, que é raro o governo, a sociedade ou oEstado que não proclama democrático. No entanto, se buscarmosdebaixo desse termo a sua real denotação, arriscamo-nos a mesmadecepção angustiante que varou o coração de Bruto, quando o romanopercebeuquanto valia avirtude. Entretanto, a democracia, nem por isso, deixou de ser apotente força condutora dos destinos da sociedade contemporânea. ${ }^{39}$ De tal ordem é ainda, pois, o seu prestígio, que constitui pesado insulto,verdadeiro agravo, injúria talvez, dizer a um governo que seuprocedimento se aparta das regras democráticas do poder.

Por isso, discutir as condições de possibilidade da decisão jurídica é, antes de tudo, uma questão de democracia. Na verdade, o "drama"é que a discricionariedade transforma os juízes em legisladores. E, para além disso, esse poder discricionário propicia a "criação" do próprio objeto de "conhecimento", típica manifestação do positivismo ${ }^{40}$. Ou seja, a razão humana passa a ser a fonteiluminadora do significado de tudo o que pode ser enunciado sobre a realidade. As coisas são reduzidas aos nossos conceitos e às nossas concepções de mundo, ficando à disposição de um protagonista (intérprete lato sensu). ${ }^{41}$ Em que lugar isso pode ser considerado democracia?

cujo fundamento racional, como diz os juristas, aplica-se ao caso em juízo (DWORKIN, Ronald. Levando os Direitos a Sério. Trad. Nelson Boeira. São Paulo: Martins Fontes, 2002, p. 165).

${ }^{38}$ DWORKIN, Ronald. O Império do Direito.Trad. Jeferson Luiz Camargo. São Paulo: Martins Fontes, 1999, p. 409 e 419.

${ }^{39}$ BONAVIDES, Paulo. Ciência Política. 10aㅡ ed. São Paulo: Malheiros, 2000, p. 345.

${ }^{40}$ Quando falamos em positivismos e pós-positivismos, torna-se necessário, já de início, deixar claro o "lugar da fala", isto é, sobre "o quê" estamos falando. Com efeito, o positivismo objeto da Nova Crítica do Direito inaugurada por Streck, sob cujos aportes o texto é desenvolvido, é, primordialmente, o positivismo normativista pós-kelseniano, isto é, o positivismo que admite discricionariedades (ou decisionismos e protagonismos judiciais). Isto porque resta considerosuperado o velho positivismo exegético, não sendo (mais) necessário dizer que o "juiz não é a boca da lei", podendo sermos poupados, nesta quadra da história, dessas"descobertas polvolares", que não podem implicar um império de decisões solipsistas, das quais são exemplos as posturas caudatárias da jurisprudência dos valores (que foi "importada" de forma equivocada da Alemanha), os diversos axiologismos, o realismo jurídico (que não passa de um "positivismo fático"), a ponderação de valores (pela qual o juiz literalmente escolhe um dos princípios que ele mesmo elege prima facie), etc. (STRECK, Lenio Luiz. Aplicar a "letra da lei" é uma atitude positivista? Revista Novos Estudos Jurídicos, v. 15, n. 1, janeiro/abril 2010, p. 160).

${ }^{41}$ STRECK, Lenio Luiz. O que é isto - decido conforme minha consciência? $2^{2}$ ed. Porto Alegre: Livraria do Advogado, 2010, p. 93. 
A Grécia foi, pois, o berço da democracia direta, mormente Atenas, onde o povo, reunido no Ágora, para o exercício direto e imediato do poder político, transformava a praça pública "no grande recinto da nação". A democracia antiga era a democracia de uma cidade, de um povo que desconhecia a vida civil, que se devotava por inteiro à coisa pública, que deliberava com ardor sobre as questões do Estado, que fazia de sua assembléia um poder concentrado no exercício da plena soberania legislativa, executiva e judicial. ${ }^{42} \mathrm{~A}$ moderna democracia ocidental, de feição tão distinta da antigademocracia, tem por bases principais a soberania popular, como fontede todo o poder legítimo, que se traduz através da vontade geral (avolonté générale do Contrato Social de Rousseau); o sufrágio universal,com pluralidade de candidatos e partidos; a observância constitucionaldo princípio da distinção de poderes, com separação nítida no regimepresidencial e aproximação ou colaboração mais estreita no regimeparlamentar; a igualdade de todos perante a lei; a manifesta adesão aoprincípio da fraternidade social; a representação como base dasinstituições políticas; a limitação de prerrogativas dos governantes; oEstado de direito, com a prática e proteção das liberdades públicas porparte do Estado e da ordem jurídica, abrangendo todas asmanifestações de pensamento livre: liberdade de opinião, de reunião, deassociação e de fé religiosa; a temporariedade dos mandatos eletivos e,por fim, a existência plenamente garantida das minorias políticas, comdireitos e possibilidades de representação, bem como das minoriasnacionais, onde estas porventura existirem.

Interessante, nesse contexto, é metáfora trazida por Warat acerca do olhar substituído pela imagem: Cuba transita pelo chamado período especial, onde a luta pelos alimentos transformou-se numa penúria quotidiana. Os cubanos, que fazem da festa de casamento uma ilusão irrenunciável (sonham por anos pelo bolo de noiva para seus filhos), tem sérias dificuldades para conseguir os ingredientes da insubstituível torta. Por isso, muitos casais optam por construir um bolo de papelão, especialmente fabricado para que se possa tirar uma foto. O que conta é a imagem, o artifício. A imagem desprendida do que tem que ser visceral. A foto e seus truques em lugar do olhar.

$\mathrm{O}$ autor ressalta que numa etapa como a atual, onde cinicamente se produzem televisivamente as múltiplas formas de dissuasão do político-economico-afetivo, é preciso dirigir um olhar em direção aos indizíveis, ao que não

\footnotetext{
42 A escura mancha que a crítica moderna viu na democracia dos antigos veio, porém, da presença da escravidão. A democracia, como direito de participação no ato criador da vontade política, era privilégio de íntima minoria social de homens livres apoiados sobre esmagadora maioria de homens escravos. Motivo pelo qual autores mais rigorosos asseveram que não houve naGrécia democracia verdadeira, mas aristocracia democrática, o queevidentemente traduz um paradoxo. Ou democracia minoritária, comoquer Nitti, reproduzindo aquele pensamento célebre de Hegel, em que ofilósofo compendiou, com luminosa clareza, o progresso qualitativo equantitativo da civilização clássica, tocante à conquista da liberdadehumana. Com efeito, disse Hegel que o Oriente fora a liberdade de umsó, a Grécia e Roma a liberdade de alguns, e o mundo germânico, ouseja, o mundo moderno, a liberdade de todos (BONAVIDES, Paulo. Ciência Política. $10^{\underline{a}}$ ed. São Paulo: Malheiros, 2000, p. 346-7 e 354).
} 
se permite dizer. Em outras palavras, encontrar-se com o que não se permite dizer(que é no fundo o inconsciente político). Encontrar-se com a outra da lei, que é o novo lugar do Estado de Direito e da dogmática jurídica. Uma nova forma de exercício da cidadania - o direito a dizer o indizível. O direito a que o corpo da lei receba seus indizíveis. Contudo-entretanto-todavia(!), parece óbvio que o que não pode ser dito pela lei, nunca será dito quando se lhe ignore. Ignorá-la é deixar, pois, exposto o indizível aos oportunismos de toda cor, o que só demonstraria que não existe compromisso com o outro sem a lei, que haveria uma volta ao estado de horda. ${ }^{43} \mathrm{O}$ homem tem que se comprometer, porquanto, com o outro.

A doutrina, não obstante, indicao caminho para a interpretação, colocando a consciência ou a convicção pessoal como norteadores do juiz, perfectibilizando essa "metodologia" de vários modos, que aparecerá como na direta aposta na ${ }^{44}$ : (a) interpretação como ato de vontade do juiz ou no adágio "sentença como sentire"; (b) interpretação como fruto da subjetividade judicial; (c) interpretação como produto da consciência do julgador; (d) crença de que o juiz deve fazer a "ponderação de valores" a partir de seus "valores"; (e) razoabilidade e/ou proporcionalidade como ato voluntarista do julgador; (f) crença de que "os casos difíceis se resolvem discricionariamente"; (g) cisão estrutural entre regras e princípios ${ }^{45}$, em que estes proporciona(ria)m uma "abertura se sentido" que deverá ser preenchida e/ou produzida pelo intérprete.

Só que, nas palavras de Grau, a decisão justa há de, para ser justa, ser conforme uma lei preexistente; mas a interpretação dessa lei, que a decisão pressupõe, há de ser re-instauradora, re-inventiva, livre; daí que a decisão justa há de ser,há um tempo só, regrada e sem regra, há de conservar a regra (a lei, rectius o direito) e destruí-la ou suspendê-la para reinventá-la em cada caso, posto que cada caso é um caso, cada decisão é diferente e requer uma interpretação absolutamente única, que nenhuma regra existente ou codificada pode, nem deve absolutamente garantir, como preceitua o autor, utilizando-se das palavras de Derrida e da síntese de Paolo Grossi, segundo a qual são duas as forças que, em direções opostas, percorrem o direito - uma tendente à rigidez, outra à elas-

${ }^{43}$ WARAT, Luis Alberto. Introdução Geral ao Direito III: o direito não estudado pela teoria jurídica moderna. Porto Alegre: Sergio Antonio Fabris, 1997, p. 141.

${ }^{44}$ STRECK, Lenio Luiz. O que é isto - decido conforme minha consciência? $2^{\mathrm{a}}$ ed. Porto Alegre: Livraria do Advogado, 2010, p. 33.

45 Como aponta Streck, as posturas voluntaristas do direito acabaram por dar azo a uma verdadeira fábrica de princípios, fenômeno ao qual o autor denomina de panprincipiologismo, que acaba, pois, por fragilizar de sobremodo o grau de autonomia que deve ter o direito na contemporaneidade. Ocorre que um dos chavões com que a discussão vem sendo posta é que, no novo constitucionalismo, ocorreu a "positivação de valores". Esse anúncio, assim apresentado, acaba por facilitar a criação, em um segundo momento, de todo tipo de princípio, como se o paradigma do Estado Democrático de Direito fosse a pedra filosofal da legitimidade principiológica, da qual pudessem ser retirados tantos princípios quantos necessários para solver os casos difíceis ou corrigir as incertezas da linguagem (STRECK, Lenio Luiz. Hermenêutica Jurídica e(m) Crise: uma exploração hermenêutica da construção do Direito. $10^{\mathrm{a}}$ Ed. Porto Alegre: Livraria do Advogado, 2011, p. 146-7). 
ticidade; e duas são as exigências fundamentais que nele se manifestam - a da certeza e liberdade individual garantidas pela lei no sistema do direito burguês e a da sua contínua adequação ao devir social, garantida pela interpretação. Aquela apenas será assegurada na medida em que o texto vincule o intérprete; esta demanda criatividade que pode fazê-lo ir além do texto, o que somente podeser compreendido se nos dispusermos a admitir que texto e norma não se superpõem, que o processo legislativo termina no momento do texto - a norma virá depois, produzida no bojo de um outro processo ${ }^{46}$, a interpretação.

Sucede que se vive ainda certa dificuldade em separar aquilo que é singular, referente a sujeitos que pensam e falam, e aquilo que faz parte da argumentação que esses sujeitos desenvolvem, utilizando os discursos lógicos. Tradicionalmente, dizia-se que isso era devido à impossibilidade de separar, em certos tipos de discursos, sujeito e objeto. O sujeito sempre estava envolvido no objeto e, no objeto, de alguma maneira, antecipávamos a análise do sujeito. ${ }^{47}$ Mas isso é uma formulação muito geral, posto que exige uma soma de critérios para que se possa dizer o que significa essa imbricação entre o sujeito e objeto no discurso.

Os juristas não perceberam, pois, que ocorreu a invasão da filosofia pela linguagem (linguistic turn, que, no plano da hermenêutica filosófica, designa-segiro ontológico), a partir de uma pós-metafísica de (re)inclusão da faticidade que, de forma inapelável, mormente a partir da década de 50 do século passado, atravessará o esquema sujeito-objeto, estabelecendo uma circularidade virtuosa na compreensão. Desse modo, odéficit de realidade produzido pelas posturas jusfilosóficas, ainda prisioneiras do esquema sujeito-objeto, será preenchido pelas posturas interpretativas, especialmente as hermenêutico-ontológicas, que deixam de hipostasiar o método e o procedimento, colocando o locusda compreensão no modo-de-ser e na faticidade (mundo prático), bem na linha da viragem ocorrida a partir de Wittgenstein e Heidegger. Assim sendo, salta-se do fundamentar,enquanto busca de um fundamentuminconcussum, em direção do compreender ${ }^{48}$, onde este não é mais um agir do sujeito, mas, sim, um modo-de-ser que se dá em uma intersubjetividade.

O depois, ao qual a pré-compreensão fornece o antes do que, seria conseqüentemente o enunciado, se já não a própria linguagem. A pré-estrutura significa, pois, que o Dasein ${ }^{49}$, o ser-aí humano, se caracteriza por uma inter-

${ }^{46}$ GRAU, Eros Roberto. O Futuro do Direito. In: NUNES, António Joé Avelãs; COUTINHO, Jacinto Nelson de Miranda (Coord.). O Direito e o Futuro: o futuro do direito. Coimbra: Almedina, 2008, p. p. $588-9$.

${ }^{47}$ STEIN, Ernildo. Aproximações sobre Hermenêutica. 2a ed. Porto Alegre: EDIPUC, 2004, p. 14. 48 STRECK, Lenio Luiz. Hermenêutica, neoconstitucionalismo e "o problema da discricionariedade dos juízes". Revista Eletrônica do Curso de Direito da OPET, v. 1, n. 1, julho/ setembro 2009, p. 197.

49 Trata-se do termo a partir do qual Heidegger designa o ser humano para analisar as estruturas fáticas da existência. Daseiné um tipo de ente que, em seu modo de ser, possui como possibilidade a compreensão do seu ser e do ser dos demais entes intramundanos. Heidegger, nesse enfoque, oferece ao termo uma conotação diferenciada que mantém o significado inicial de existência, mas no sentido daquele ente que, entre todos os outros, existe, que é o ser humano. Para Heidegger, 
pretação que lhe é peculiar e que se encontra antes de qualquer locução ou enunciado ${ }^{50}$ - uma interpretação, cujo caráter fundamental de cuidado ameaça ocultar a tendência niveladora do juízo proposicional.

O círculo hermenêutico pressupõe, nesse desiderato, um enlace dialético em que a compreensão se molda no processo relacional entre a consciência histórica do intérprete e a abertura interpretativa permitida pelo objeto a partir de seu mundo particular. O círculo, portanto, não é de natureza formal. Não é nem objetivo nem subjetivo, descrevea compreensão como a interpretação do movimento da tradição e do movimento do intérprete. A antecipação de sentido, que guia a nossa compreensão de um texto, não é, pois, um ato da subjetividade, já que se determina a partir da comunhão que nos une com a tradição. Porém, essa nossa relação com a tradição, essa comunhão, esta submetida a um processo de contínua formação. Não se trata simplesmente de uma pressuposição, sob a qual nos encontramos sempre, mas sim nós mesmos vamos instaurando-a, na medida em que compreendemos, em que participamos do acontecer da tradição e continuamos determinando-o, assim, a partir de nós próprios. O círculo metodológico, de tal sorte, descreve um momento estrutural ontológico da compreensão ${ }^{51}$, ocorrendo no instante em que o sujeitoparticipa na construção do sentido do objeto moldado por tais pré-juízos, ao passo que o próprio objeto, no desenrolar do processo hermenêutico, modifica a compreensão do intérprete.

Como representação da circularidade da compreensão, o mesmoapresenta um significado ontológico positivo, eis que, a partir de suacompreensão, ao invés de apenas se deixar guiar e simplesmente reproduzirpré-juízos anteriores, o sujeito tem a possibilidade de chegar à coisa mesma, atingir um conhecimento originário, substituindo conceitos ingênuos e inconscientespela elaboração de uma concepção prévia, consciente e legítima, baseadana sua historicidade e temporalidade. Para Heidegger, o círculo não deve ser rebaixado a um vitiosum. Nele se esconde a possibilidade doconhecimento mais originário que, de certo, só pode ser apreendidade modo autêntico se a interpretação tiver compreendidoque sua primeira, única e última tarefa é de não se deixarguiar, na posição prévia, visão prévia e concepção prévia, porconceitos ingênuos e "chutes". Ela deve, na elaboração da posiçãoprévia, visão prévia e concepção prévia, assegurar o temacientífico a partir das coisas mesmas, porque a compreensão,de acordo com seu sentido existencial, é o poder-ser daprópria pre-sença.As pressuposições ontológicas do conhecimentohistórico ultrapassam, em princípio, a idéia de rigordas ciências

assim, somente o Dasein existe, porque existência implica possibilidades, projetos. Os demais entes intramundanos, que estão à disposição subsistem (STRECK, Lenio Luiz. Hermenêutica Jurídica e(m) Crise: uma exploração hermenêutica da construção do Direito. 10ª ed. Porto Alegre: Livraria do Advogado, 2011, p. 235-6).

${ }^{50}$ GRONDIN, Jean. Introdução à Hermenêutica Filosófica. Trad. Benno Dischinger. São Leopoldo: UNISINOS, 1999, p. 159.

51 GADAMER, Hans-Georg. Verdade e Método: traços fundamentais de uma hermenêutica filosófica. $2^{\mathrm{a}}$ ed. Petrópolis: Vozes, 1998, p. 439-40. 
mais exatas. A matemática não é mais rigorosado que a história ${ }^{52}$, sendo apenas mais restrita no âmbitodos fundamentos que lhe são relevantes.

O ser humano interpreta, então, em virtude da denominada fusão de horizontes -a compreensão se dá como evento no momento em que há uma interação entre o mundo daquilo que se conhece (horizonte de experiência no qual foi produzido) e o mundo daquele que se propõe a conhecer (horizonte de experiência no qual se situa o observador). Há por isso, também uma interação circular entre passado e presente - só compreendemos em virtude de uma consciência que se situa agora, neste momento, mas que, por sua vez, possui como condição de compreensão a operacionalidade do passado, que nela se faz atual por meio das pré-compreensões por esse transmitidas. Na verdade, o horizonte do presente está num processo de constante formação, na medida em que estamos obrigados a pôr à prova constantemente todos nossos pré-juízos. Parte dessa prova é o encontro com o passado e a compreensão da tradição da qual nós mesmos procedemos. O horizonte do presente não se forma, pois,à margem do passado. Nem mesmo existe um horizonte do presente por si mesmo, assim como não existem horizontes históricos a serem ganhos. Antes, compreender é sempre o processo de fusão desses horizontes ${ }^{53}$ presumivelmente dados por si mesmos.

Por seu turno, essa fusão de horizontes leva a outro tipo de fusão, qual seja, a dos momentos de compreensão, interpretação e aplicação, vistos pela velha tradição hermenêutica como atividades distintas.A impossibilidade dessa cisão implica, porquanto, a impossibilidade de ointérprete "retirar" do texto "algo que o texto possui-em-si-mesmo", numa espécie de Auslegung,como se fosse possível reproduzir sentidos; ao contrário, para Gadamer, fundado na hermenêuticafilosófica, o intérprete sempre atribui sentido (Sinngebung). Mais ainda, essa impossibilidade da cisão- que não passa de um dualismo metafísico - afasta qualquer possibilidade de fazer "ponderações emetapas", circunstância, aliás, que coloca a(s) teoria(s) argumentativa(s) como refém(ns) doparadigma do qual tanto tentam fugir: a filosofia da consciência. ${ }^{54}$ Para Gadamer, nessa esteira, a interpretação nada mais é do que a forma explícita da compreensão e não um momento distinto desta. Igualmente, a aplicação não se realiza posteriormente a essas, mas integra o próprio ato de compreender. Desse modo, não se compreende para depois aplicar o compreendido a algo, mas compreende-se aplicando.

${ }_{52}$ HEIDEGGER, Martin. Ser e tempo. Vol. 1. 13ª ed. Petrópolis: Vozes, 2004, p. 210.

${ }^{53}$ O projeto de um horizonte histórico é, portanto, só uma fase ou momento na realização, e não se prende na auto-alienação de uma consciência passada, mas se recupera no próprio horizonte compreensivo do presente. Na realização da compreensão tem lugar uma verdadeira fusão horizôntica que, com o projeto do horizonte histórico,leva a cabo simultaneamente sua suspensão (GADAMER, Hans-Georg. Verdade e Método: traços fundamentais de uma hermenêutica filosófica. 2a ed. Petrópolis: Vozes, 1998, p. 457-8).

${ }^{54}$ STRECK, Lenio Luiz. Aplicar a "letra da lei" é uma atitude positivista? Revista Novos Estudos Jurídicos, v. 15, n. 1, janeiro/abril 2010, p. 162. 
O ser humano, como ser-no-mundo, desde sempre já se compreende a si mesmo no mundo, mas só se compreende a si mesmo no mundo porque já antecipou sempre uma compreensão do ser. Compreensão do ser não é de um ser objetivo, objeto, mas compreensão da totalidade. Este elemento prático que Heidegger introduz na hermenêutica é absolutamente novo. Antes a hermenêutica era o compreender de textos, compreender determinados universos culturais, era no fundo, um interpretar que trata de objetos. Agora o compreender é um compreender que se constitui como totalidade, porque é um compreender do mundo, mas não de um mundo como um continente de conteúdos, mas de um mundo que é a própria transcendência. Este mundo que ao mesmo tempo somos nós e projetamos sobre tudo o que deve se dar. Assim vai-se formar a chamada estrutura da circularidade, isto quer dizer, na medida em que já sempre somos mundo e ao mesmo tempo projetamos mundo. ${ }^{55}$ Estamos envolvidos com os objetos do mundo e descrevemos o mundo no qual se dão os objetos.

Em realidade, a interpretação quer ajudar a pré-compreensão a ser transparente. Ela serve, em primeira linha, à apropriação da própria situação de compreensão e à dos pressupostos, que determinam o preocupado conhecimento e comportamento. Seu aguilhão crítico está na tentativa de evitar, dentro do possível, o equívoco pessoal. Já que nossa compreensão pode equivocar-se, cada esforço de compreensão necessita da apropriação, da confirmação e da preservação. Dessa forma, a primeiríssima tarefa de qualquer interpretação sincera deve ser a de trazer à consciência a própria pré-estrutura da compreensão. ${ }^{56}$

\section{O DEVER DE JUSTIFICAÇÃO DAS DECISÕES E O DIREITO A OBTENÇÃO DE RESPOSTAS CORRETAS CONSTITUCIONALMENTE}

Dworkin,analisando o direito como interpretação, inicia sua avaliação questionando se não existe mesmo nenhuma resposta certa em casos controversos, ilustrando seu pensamento com a suposição de aprovação de uma lei estipulando que,contratos sacrílegos, de agora em diante, seriam inválidos. O autor retrata, trabalhando com seu exemplo, que a comunidade estaria dividida quanto se um contrato assinado no domingo seria, apenas por essa razão, sacrílego. Denuncia, acerca disso, que bem poucos legisladores tinham, provavelmente, essa questão em mente quando votaram, e agora estão igualmente divididos quanto se ela deve ser interpretada assim. Tom e Tim, pois, assinaram um contrato no domingo, e agora Tom processa Tim para fazer cumprir os termos do contrato, cuja validade Tom contesta. Diremos que o juiz deve buscar a resposta certa para a questão de se o contrato de Tom é valido, mesmo que a comunidade esteja dividida quanto a qual é a resposta certa? Ou é mais realista

55 STEIN, Ernildo. Aproximações sobre Hermenêutica. 2a ed. Porto Alegre: EDIPUC, 2004, p. 66.

${ }^{56}$ GRONDIN, Jean. Introdução à Hermenêutica Filosófica. Trad. Benno Dischinger. São Leopoldo: UNISINOS, 1999, p. 165. 
Com efeito, se, durante o regime autoritário, buscávamos as brechas da lei e lutávamos a partir dessa frágil institucionalidade apostando em um antidedutivismo e em posturas que fizessem com que aquele direito fosse arrazado pela faticidade, agora, em plena produção democrática do direito, não parece ter muito sentido continuarmos a apostar em um protagonismo vencido pelos acontecimentos que culminaram na elaboração de um novo texto constitucional. Em outras palavras, antes não tínhamos Constituição (e tampouco democracia) e éramos obrigados a ser "realistas" ou "pragmatistas"; hoje, temos uma Constituição que deve ser o alfa e o ômega da conduta dos juristas ${ }^{58} \mathrm{e}$, por isso, a tarefa de qualquer teoria do direito preocupada com a democracia e os direitos fundamentais deve ser a de concretizar a Constituição. Isso significa dizer que não há mais espaços para voluntarismos e decisionismos baseados em discursos com pretensão corretiva.

Tendo em vista isso, propondo usar a interpretação literária como um modelo para o método central da análise jurídica, Dworkin trabalha com a idéia de que um autor é capaz de separar o que escreveu de suas intenções e crenças anteriores, de tratá-lo como um objeto em si. É capaz de chegar a novas conclusões sobre sua obra, fundamentadas em juízos estéticos - de que seu livro é mais coerente, uma análise melhor de temas mais importantes, interpretados de maneira um tanto diferente da que pensou quando estava escrevendo. Este é um fato importante por várias razões, fala o mesmo, usando novamente Fowles - desta vez comotestemunho - para quem apenas umacoisa é compartilhada por todos nos romancistas, qual seja, o desejo de criar mundos tão reais quanto o mundo que é, mas diferentes. É por isso, afirma, que não podemos planejar, eis que sabemos que um mundo genuinamente criado deve ser independente de seu criador.

O autor, ilustra o presente, trabalhando com a idéia de um grupo de romancistas contratado para um determinado projeto e que jogue dados para definir a ordem do jogo. ${ }^{59} \mathrm{O}$ de número mais baixo escreve o capítulo de abertura de

${ }^{57}$ DWORKIN, Ronald. Uma Questão de Princípio. Trad. Luís Carlos Borges. São Paulo: Martins Fontes, 2001, p. 175.

${ }^{58}$ Não obstante, a dogmática - entendida em seusentido mais tradicional - continua dominando as práticas jurídicas, a ponto de colocar a doutrinacomo refém de uma jurisprudência construída ad hoc, em que o "caso jurídico" assume a função deálibi para construções pragmatistas, como se o direito (produzido democraticamente com berçoconstitucional) não tivesse "DNA" (STRECK, Lenio Luiz. O direito de obter respostas constitucionalmente adequadas em tempos de crise do direito: a necessária concretização dos direitos humanos. Revista Latinoamericana de Derechos Humanos, v. 1, n. 1, julho/2010, p. 100).

${ }_{59}$ Antes, porém, reconhece que as observações preliminares sobre a interpretação literária podem ter sugerido uma distinção muito nítida entre o papel do artista na criação de uma obra de arte e o do crítico que a interpreta posteriormente, eis que se concebe que (i) o artista não pode criar nada sem interpretar enquanto cria; como pretende criar arte, deve pelo menos possuir uma teoria tácita de por que aquilo que produz é arte e por que é uma obra de arte melhor graças a este, e não àquele golpe do pincel, da pena ou do cibzel; (ii) o crítico, por sua vez, cria quando interpreta; pois embora seja limitado pelo fato da obra, definido nas partes mais formais e acadêmicas de sua teoria da arte, seu senso artístico mais prático está comprometido com a responsabilidade de decidir qual maneira de ver, ler ou compreender aquela obra a mostrar como arte melhor. 
um romance, que ele depois manda para o número seguinte, o qual acrescenta um capítulo, com a compreensão de que está acrescentando um capítulo a esse romance, não começando outro, e, depois, manda os dois capítulos para o número seguinte, e assim por diante. Nessa linha, cada romancista, a não ser o primeiro, tem a dupla responsabilidade de interpretar e criar, pois precisa ler tudo o que foi feito antes para estabelecer, no sentido interpretativista, o que é o romance criado até então. Deve decidir como os personagens são realmente, que motivos os orientam, qual é o tema ou o propósito do romance em desenvolvimento, até que ponto algum recurso ou figura literária, consciente ou inconscientemente usado, contribui para estes, e se deve ser ampliado, refinado, aparado ou rejeitado para impelir o romance em uma direção e não em outra. Esse estilo de interpretação, porquanto, não deve restar subordinado à intenção, eis que, pelo menos para todos os romancistas após o segundo, não há um único autor cujas intenções qualquer intérprete possa, pelas regras do projeto, considerar como decisivas.

Conclui, então, que cada juiz é como um romancista na corrente. Ele deve ler tudo o que outros juízes escreveram no passado, não apenas para descobrir o que disseram, ou seu estado de espírito quando o disseram, mas para chegar a uma opinião sobre o que esses juízes fizeram coletivamente, da maneira como cada um dos romancistas formou uma opinião sobre o romance coletivo escrito até então. Qualquer juiz obrigado a decidir uma demanda descobrirá, de tal modo, se olhar nos livros adequados, registros de muitos casos plausivelmente similares, decididos há décadas ou mesmo séculos por muitos outros juízes, de estilos e filosofias judiciais e políticas diferentes, em períodos nos quais o processo e as convenções judiciais eram diferentes. Ao decidir o novo caso, cada juiz deve considerar-se como parceiro de um complexo empreendimento em cadeia, do qual essas inúmeras decisões, estruturas, convenções e práticas são a historia ${ }^{60}$; é seu trabalho continuar essa história no futuro por meio do que ele faz agora.

Não obstante isso, ao invés de avançar em direção ao novo, o velho senso comum teórico - forjado em perspectivas positivistas-pragmatistas transformou o direito em um somatório de decisões desconectadas, é dizer, em um verdadeiro "estado de natureza hermenêutico", no interior do qual cada juiz decide como mais lhe aprouver. Sob o álibi da "abertura interpretativa" proveniente da principiologia constitucional, parece não haver limites para a "criatividade", a ponto de, por vezes, soçobrar o próprio texto constitucional. A Constituição, que deveria ser o locus privilegiado para a obtenção de respostas concretizadoras, foi, ela mesma, transformada em um "texto aberto", por vezes, panprincipiologista. A grande evolução do neo-constitucionalismo em garantir a recuperação do ideal de justiça ao dotar normativamente os princípios (e a

Há, porquanto, uma diferença entre interpretar quando se cria e criar quando se interpreta e, portanto, uma diferença reconhecível entre o artista e o crítico, a qual, não obstante, pode ser derrubada em certas circunstâncias (DWORKIN, Ronald. Uma Questão de Princípio. Trad. Luís Carlos Borges. São Paulo: Martins Fontes, 2001, p. 235-7).

${ }^{60}$ DWORKIN, Ronald. Uma Questão de Princípio. Trad. Luís Carlos Borges. São Paulo: Martins Fontes, 2001, p. 238. 
inclusão da faticidade do mundo no direito) sofre, assim, um retrocesso pelo qual se procura estabelecer uma regra, geral e universalizante, que permita um julgamento massivo de todos os processos ${ }^{61}$, pressupostos como iguais.

Paradoxalmente, o método fenomenológico é o método no qual devemos dar sempre conta de dois aspectos da investigação: do aspecto da singularidade e do aspecto da sistematicidade. $\mathrm{O}$ aspecto da singularidade é, pois, a primeira parte da palavra, é o fenômeno. O aspecto da universalidade é o aspecto do logos, da logia. Então, fenomenologia já contém esta idéia de uma espécie de análise constante dos aspectos da singularidade e da universalidade. Enquanto logia, a fenomenologia trata do logos, do discurso, da manifestação. Por isso, a fenomenologia se conduz pela base da linguagem, pela base do discurso, pela análise do nível lógico-semântico. Fenomenologia trata do fenômeno, o método fenomenológico trata daquilo que se esconde sob o logos, que é a singularidade que tenta se expressar no logos, mas que o logos sempre oculta. É o elemento hermenêutico. Na fenomenologia já está sempre presente, porquanto, a compreensão enquanto um elemento fundante do processo do discurso ${ }^{62}$ que chamava, antes, o compreender no segundo sentido.

Com efeito, é possível dizer, sim, que uma interpretação é correta, e a outra é incorreta (adequada ou inadequada em relação à Constituição). A explicitação da resposta de cada casodeverá estar sustentada em consistente justificação, contendo a reconstrução do direito, doutrinariae jurisprudencialmente, confrontando tradições, enfim, colocando a lume a fundamentação jurídicaque, ao fim e ao cabo, legitimará a decisão no plano do que se entende por responsabilidade políticado intérprete no paradigma do Estado Democrático de Direito. ${ }^{63}$ Uma decisão adequada à Constituição

${ }^{61}$ Eis o problema. O princípio do due process of law, sob o seu viés substantivo, garante ao cidadão a procura do poder judiciário para que lhe proporcione uma proteção jurídica individual, para a qual se faz necessária a apreciação de todas as circunstâncias do caso concreto, aquilo alegado e provado em juízo, não se podendo tomar como base, pois, um esquema de representação fraca do fenômeno individual, muito menos do contexto histórico-factual que tal processo envolve. (STRECK, Lenio Luiz. O direito de obter respostas constitucional-mente adequadas em tempos de crise do direito: a necessária concretização dos direitos humanos. Revista Latinoamericana de Derechos Humanos, v. 1, n. 1, julho/2010, p. 101).

${ }^{62}$ A fenomenologia não é simplesmente uma análise da linguagem, mas ela tem uma pretensão maior, ela tem a pretensão de poder construir um discurso no qual os dois aspectos da linguagem estejam presentes. Isto é o que vai produzir a diferença entre filosofia analítica e fenomenologia hermenêutica. A fenomenologia hermenêutica procura dar atenção aos dois lados do discurso - ao lado hermenêutico e ao lado apofântico, que podemos chamar lógico-analítico. Heidegger orienta sua atenção, com efeito, através deste método fenomenológico, do binômio do velamento e do desvelamento. Através do velamento, o sentido mostra que algo sempre já antecipadamente se deu como condição de possibilidade do discurso que, entretanto, é ocultado pelo discurso. Quando tratamos do nível lógico-semântico de algo, estamos simplesmente pressupondo algo do qual não tratamos, mas que está presente. Esse é, de certo modo, o que nós velamos (STEIN, Ernildo. Aproximações sobre Hermenêutica. 2ª ed. Porto Alegre: EDIPUC, 2004, p. 59-60).

${ }^{63}$ Os juízes têm a obrigação de justificar suas decisões, porque com elas afetam os direitos fundamentais e sociais, além da relevante circunstância de que, no Estado Democrático de Direito, a adequada justificação da decisão constitui um direito fundamental (STRECK, Lenio Luiz. O direito de obter respostas constitucionalmente adequadas em tempos de crise do direito: a 
(respostahermeneuticamente correta) será fruto, nesse passo, de uma reconstrução histórica do direito, com respeito àcoerência e a integridade (exame da integridade legislativa e respeito a integridade das decisõesanteriores). A resposta adequada à Constituição deverá estar fundada, indo mais além,em argumentos de princípio e não em argumentos de política (teleológicos). Do mesmo modo, a resposta correta deve buscar a preservação do grau de autonomia queo direito atingiu nesta quadra da história, evitando-se os "predadores" externos, como os discursosadjudicativos provenientes da moral, da política e da economia, assim como os "predadores" internos,como os subjetivismos, axiologismos e pragmatismos de toda a espécie.

A integridade não seria necessária como uma virtude política distinta, nessa esteira,somente em um Estado utópico, em que a coerência estaria garantida porque as autoridades fariam sempre o que é perfeitamente justo e imparcial. Na política comum, porém, devemos tratar a integridade como um ideal independente se a admitirmos por inteiro, pois pode entrar em conflito com outros ideais. Pode exigir que apoiemos uma legislação que consideraríamos inadequada numa sociedade perfeitamente justa e imparcial, e que reconheçamos direitos que, segundo acreditamos, seus membros não teriam. Veja-se que um juiz que esteja decidindo o casode uma senhora que sofreu um infarto ao receber a notícia do acidente de automóvel envolvendo seu marido e seus filhos e queria receber por isso uma indenização do motorista que provocara o sinistro, poderia considerar injusta a exigência de reparação. Mas, se ele aceita a integridade e sabe que a algumas vítimas de danos morais já foi conferido o direito à indenização, terá,nesse enfoque, uma razão para se pronunciar favoravelmente. Não obstante, a integridade exigeque as normas públicas da comunidade sejam criadas e vistas, na medida do possível, de modo a expressar um sistema único e coerente de justiça e equidade na correta proporção. Uma instituição que aceite esse ideal às vezes irá, por esta razão, afastar-se da estreita linha das decisões anteriores ${ }^{64}$, em busca de fidelidade aos princípios concebidos como mais fundamentais a esse sistema como um todo.

A relação entre sistema/problema que aqui se verifica não pode ser pensada apenas na coerência do sistema pressuposto (pela integração nele da normatividade judicativa dos casos decidendos, como que numa absorção,dos casos ajuizados pelo sistema mediante a prévia intencionalidade da sua coerência normativa), mas na coerência de uma dialética em que dois pólos concorrem, cada um com a sua valência específica, na constituição unitária do resultado jurídico- o sistema é constituído em função das exigências e dos resultados da judicativa realização

necessária concretização dos direitos humanos. Revista Latinoamericana de Derechos Humanos, v. 1, n. 1, julho/2010, p. 103).

64 Durante algum tempo, os juízes ingleses declararam que embora os membros de outras profissões fossem responsáveis por danos causados por sua negligência, os advogados eram imunes a tal responsabilidade. Entendida em sentido estrito, a coerência teria exigido a continuidade dessa exceção, mas a integridade condena o tratamento especial dispensado aos advogados, menos que este possa ser justificado em princípio - o que parece improvável. A câmara dos Lordes atualmente reduziu essa isenção: ao fazê-lo, preferiu a integridade à coerência estrita (DWORKIN, Ronald. O Império do Direito. Trad. Jeferson Luiz Camargo. São Paulo: Martins Fontes, 1999, p. 264). 
do direito, o problema (o caso) é não só intencionado na sua específica problematicidade jurídica como constituído enquanto o referente concreto do juízo em função das exigências de validade da normatividade jurídica que o sistema vai objetivando. ${ }^{65} \mathrm{O}$ problema da interpretação jurídica, como problema normativo, acaba assim por ser o problema da concreta realização normativa do direito.

Deve-se ter presente, nesse contexto, que quando se está a falar/indagar acerca dopapel/função da Jurisdição Constitucional (ou do Poder Judiciário) narealização/efetivação de direitos sociais-fundamentais, é porque seestá a admitir que, primeiro, há uma inefetividade da Constituição,e, segundo, em havendo inércia dos Poderes Públicos na realização/implementação de políticas públicas aptas à efetivação dos direitossociais-fundamentais assegurados pela Lei Maior, é possível (enecessária) a intervenção da justiça constitucional. A toda evidência,tais questões implicam outras três, que se interpenetram: a) anecessidade de uma redefinição na relação entre os Poderes doEstado; b)a admissão de que a justiça constitucional possa vir ater um papel intervencionista, e c) um certo grau de dirigismo constitucional. ${ }^{66}$

Talenfoque se põe com a transformação política operada pelo Estado Democrático de Direito, quando a própria noção de democracia é transladada para um locus legitimador não mais meramente formal, senão, principalmente, substancial,apesar de tal já estar presente no âmbito do Estado Social. Isso implica, pois, que a noção de garantia não fica mais restrita aos padrões liberais de limitação negativa da ação estatal, mas vem acrescida de um plus transformador, em que a concretização de obrigações/prestações, que importam na transfiguração do status quo, assume efetivamente uma posição de primazia no espaço de legitimação constituído pela função de garantia. Com isso, a distribuição clássica das funções dos poderes públicos não mais está sujeita a uma separação rigorosa, com o objetivo de reforçar uma estrutura de fiscalização, mas, noutro sentido, se apresenta mais flexível, voltada a uma finalidade de cooperação, baseada na perspectiva de que há uma unidade inexorável no Estado para a realização

65 NEVES, A. Castanheira. O Actual Problema Metodológico da Interpretação Jurídica.Coimbra: Coimbra, 2003, p. 346.

${ }^{66}$ Em face das profundas alterações paradigmáticas ocorridas na teoria do Estado e da Constituição, a noção de Estado Democrático de Direito pressupõe uma valorização do jurídico, e, fundamentalmente, exige a (re)discussão do papel destinado ao Poder Judiciário (e à justiça constitucional) nesse (novo) panorama estabelecido pelo constitucionalismo do pós-guerra, mormente em países como o Brasil, cujo processo constituinte de 1986-88 assumiu uma postura "comunitarista", onde os constitucionalistas lutaram pela incorporação dos compromissos ético-comunitários na Lei Maior, buscando não apenas reconstruir o Estado de Direito, mas também "resgatar a força do Direito", cometendo à jurisdição a tarefa de guardiã dos valores materiais positivados na Constituição. Não se pode confundir, entretanto, a adequada/necessária intervenção da jurisdição constitucional com a possibilidade de decisionismos por parte de juízes e tribunais. Seria antidemocrático. Com efeito, defender certo grau de dirigismo constitucional e um nível determinado de exigência de intervenção da justiça constitucional não pode significar que os tribunais e assenhorem da Constituição (STRECK, Lenio Luiz. Verdade e Consenso: Constituição, Hermenêutica e Teorias Discursivas - da possibilidade à necessidade de respostas corretas em Direito. 3a ed. Rio de Janeiro: Lumen Juris, 2009, p.119). 
de valores éticos substanciais positivados constitucionalmente e intensamente reclamados pela população ${ }^{67}$, a qual está expressa em uma atribuição executiva peculiar ao espaço público (não limitada às tarefas próprias do Poder Executivo).

Os mecanismos constitucionaispostos à disposição do cidadão e das instituições devem ser utilizadoseficazmente, nesse compasso, como instrumentos aptos a evitar que os poderespúblicos disponham livremente da Constituição, cuja força normativa não pode significar a opção pelocumprimento ad hoc de dispositivos "menos significativos" da Lei Maiore o descumprimento sistemático daquilo que é mais importante -o seu núcleo essencial-fundamental. Descumprir os dispositivos que consubstanciamo núcleo básico da Constituição, isto é, aqueles que estabelecemos fins do Estado, representa solapar, por oportuno, o própriocontrato social (do qual a Constituição é o elo conteudístico queliga o político e o jurídico da sociedade). O texto constitucional, frutodesse processo de repactuação social, não pode ser transformadoem um latifúndio improdutivo. Não pode, pois, ser deslegitimado. Com efeito, o direito já não está subordinado à políticacomo se dela fosse um mero instrumento ${ }^{68}$, mas, sim, é a políticaque se converte em instrumento de atuação do direito, subordinadaaos vínculos a ela impostos pelos princípios constitucionais.

Nessa senda, Dworkin trabalha com a idéia de que as doutrinas estritas de precedente (que exigem que juízes sigam as decisões passadas de outros juízes, mesmo quando pensam que tais decisões são equivocadas) são um fato bastante comum, ilustrando o fato, contudo, de que se Hércules decidisse ignorar a supremacia legislativa e o precedente estrito sempre que a ignorância dessas doutrinas lhe permitisse aperfeiçoar a integridade do direito, considerada, por si só, matéria relevante, então ele estaria violado totalmente a integridade, eis que qualquer interpretação geral bem-sucedida de nossa prática legal deve reconhecer essas limitações institucionais. A integridade política e a justiça poderiam estar em melhor situação, em sua opinião, se o governo local e o nacional tivessem adotado, de forma mais consistente, a igualdade de recursos como a meta de seus programas econômicos. No entanto, ele próprio estaria violando a integridade se ignorasse as decisões que eles tomaram

Os tribunais são, por oportuno, as capitais do império do direito, e os juízes são seus príncipes, mas não seus videntes e profetas. O direito não é es-

${ }^{67}$ MORAIS, Jose Luis Bolzan de. Crises do estado, democracia política e possibilidades de consolidação da proposta constitucional. In: CANOTILHO, José Joaquim Gomes; STRECK, Lenio Luiz (Coord). Entre Discursos e Culturas Jurídicas. Coimbra: Coimbra, 2006, p. 29-30.

${ }^{68}$ O Poder Judiciário não pode continuar com uma postura passiva diante da sociedade. Mas, a toda evidência, quando se fala da função intervencionista do Poder Judiciário, não se está propondo uma (simplista) judicialização da política e das relações sociais (e nem a morte da política). Ou seja, onde o processo político (Legislativo, Executivo) falha ou se omite na implementação de políticas públicas e dos objetivos sociais nela implicados, cabe ao Poder Judiciário tomar uma atitude ativa na realização desses fins sociais através da correição de prestações dos serviços sociais básicos (STRECK, Lenio Luiz. Jurisdição Constitucional e Hermenêutica: Perspectivas e Possibilidades de Concretização dos Direitos Fundamentais-Sociais no Brasil. Revista Novos Estudos Jurídicos, v. 8, n. 2, maio/aagosto 2003, p. 281). 
gotado por nenhum catálogo de regras ou princípios, cada qual com seu próprio domínio sobre uma diferente esfera de comportamentos. Tampouco por alguma lista de autoridades com seus poderes sobre parte de nossas vidas.O império do direito é definido pela atitude, não pelo território, o poder ou o processo. É uma atitude interpretativa e auto-reflexiva, dirigida à política no mais amplo sentido. É uma atitude contestadora que torna todo cidadão responsável por imaginar quais são os compromissos públicos de sua sociedade com os princípios, e o que tais compromissos exigem em cada nova circunstância. O caráter contestador do direito é confirmado, assim como é reconhecido o papel criativo das decisões privadas, pela retrospectiva da natureza judiciosa das decisões tomadas pelos tribunais, e também pelo pressuposto regulador de que, ainda que os juízes devam sempre ter a última palavra, sua palavra não será a melhor por essa razão. A atitude do direito é construtiva: sua finalidade, no espírito interpretativo, é colocar o princípio acima da prática para mostrar o melhor caminho para um futuro melhor, mantendo a boa-fé com relação ao passado ${ }^{69}$ É, por último, uma atitude fraterna, uma expressão de como somos unidos pela comunidade apesar de divididos por nossos interesses e convicções.

Em outras palavras, efetivamente há um direito fundamental a que aConstituição seja cumprida. Trata-se de um direito fundamental a uma respostaadequada à Constituição ou, se assim se quiser, uma resposta constitucionalmenteadequada (ou, ainda, uma resposta hermeneuticamente correta em relação àConstituição). Antes de qualquer outra análise, deve-se sempre, porquanto, perquirir acompatibilidade da norma jurídica com a Constituição (entendida,à evidência, no seu todo principiológico) e a existência de eventual antinomia..$^{70}$ A respostaconstitucionalmente adequada, enquanto direito fundamental do cidadão, diante disso, é a explicitaçãodas condições de possibilidade a partir das quais é possível desenvolvera idéia do que significa fundamentar e do que significa justificar.

Assim sendo, confirma Streck, a decisão (resposta) estará adequada na medida em que for respeitada,em maior grau, a autonomia do direito (que se pressupõe produzido democraticamente), evitada a discricionariedade (além da abolição de qualquer atitude arbitrária) e respeitada a coerência e a integridade do direito, a partir de uma detalhadafundamentação. Haverá coerência se

${ }^{69}$ DWORKIN, Ronald. O Império do Direito. Trad. Jeferson Luiz Camargo. São Paulo: Martins Fontes, 1999, p. 486 e 492.

${ }^{70}$ Deve-se sempre perguntar se, à luz dos princípios e dos preceitos constitucionais, a norma é aplicável àquela situação hermenêutica. Mais ainda, há de se indagar em que sentido aponta a précompreensão, condição para a compreensão do fenômeno. Para interpretar, é necessário, primeiro, compreender o que se quer interpretar. Nesse sentido, os conceitos jurídicos (enunciados lingüísticos que pretendem descrever o mundo, epistemologicamente) não são o lugar dessa resposta (constitucionalmente adequada), mas essa resposta será o lugar dessa "explicitação", que, hermeneuticamente, não se contenta com uma fundamentação assertórica/semântica, porque nela - nessa resposta - há um elemento a priori, sustentado na pré-compreensão e no mundo prático (STRECK, Lenio Luiz. Da "justeza dos nomes" à "justeza da resposta" constitucional. Revista do Instituto de Pesquisas e Estudos de Bauru, v. 43, n. 50, julho/dezembro 2008, p. 108). 
os mesmos princípios que foram aplicadosnas decisões o forem para os casos idênticos; mas, mais do que isso, estará asseguradaa integridade do direito a partir da força normativa da Constituição $\mathrm{o}^{71}$, possuindo, pois, a resposta correta (adequada) um grau de abrangênciaque evita decisões ad hoc.

Não esgotará o juiz, de tal sorte, a sua atividade com a indicação de que tal ou qual norma legal incidiu sobre o julgado; ele não poderá escolher livremente o sentido que lhe pareceu adequado. Deve, apoiado nas circunstâncias do caso, indicar as razões pelas quais optou por um e não por outro dos sentidos possíveis da norma. Vale dizer, a exigência é a de que a motivação do ato jurisdicional seja completa, abrangendo tanto a versão aceita pelo julgador quanto as razões pelas quais ele recusara a versão oposta, e isso porque o convencimento judicial deve alcançar o nível de racionalidade exigido pela lei; a sentença deve conter, pois, argumentos convincentes sobre a impropriedade ou a insuficiência das razões ou fundamentos de fato e de direito usados pelo sucumbente ${ }^{72}$, de modo que a fundamentação deve ser ampla, compreensiva de todos os aspectos relevantes do conflito, em especial, a análise crítica dos fatos.

A obrigatoriedade de fundamentação das decisões judiciaispossui, pois, cariz democrático, em face da garantia que proporciona contra o arbítrio e a discricionariedade do juiz. No entanto, fundamentar validamente não é explicar a decisão. A explicação só confere à decisão uma falsa aparência de validade. $\mathrm{O}$ juiz explica, e não fundamenta, quando diz que assim decide por ter incidido ao caso tal ou qual norma legal. A atitude do juiz que repete o texto normativo que lhe pareceu adequado, sem justificar a escolha, não vai além do que faria se não explicitasse de forma alguma o motivo da decisão. Ao juiz contemporâneo não pode bastar, ao dar cabo a uma discussão, a mera declaração do vencedor, repetindo as razões deste, como quem enuncia uma equação matemática. ${ }^{73}$ Ao contrario, é preciso que o julgador, no mesmo passo em que diz por que acolheu as razões do vencedor, afirme as razões pelas quais rejeitara a interpretação dada pela parte sucumbente.

O direito a fundamentação das decisões judiciais é, em última análise, um direito fundamental, pois é garantia mínima para o desenvolvimento e ou a manutenção do Estado de Direito. $\mathrm{O}$ direito à fundamentação é assegurado a cada cidadão e a toda a coletividade sociedade que dessa fundamentação se aproveita, seja para saber as razões de decidir do julgador, seja para controlar a

${ }^{71}$ STRECK, Lenio Luiz. Da "justeza dos nomes" à "justeza da resposta" constitucional. Revista do Instituto de Pesquisas e Estudos de Bauru, v. 43, n. 50, julho/dezembro 2008, p. 112.

72 Para Ovídio, as soluções do direito não são certas ou erradas, e isso porque a história também não pode ser compreendida como certa ou errada - elas serão apenas razoáveis; contudo, deverão ser suficientemente razoáveis, ou seja, alicerçadas em fundamentos válidos, onde não estejam ocultas as verdadeiras razões de decidir. Desta sorte, parte-se do princípio de que o texto legal deve ser hermeneuticamente compreendido(BAPTISTA DA SILVA, Ovídio. Jurisdição, Direito Material e Processo. Rio de Janeiro: Forense, 2008, p. 140-1, 148-9 e 150).

${ }^{73}$ BAPTISTA DA SILVA, Ovídio. Fundamentação das sentenças como garantia constitucional. Revista do Instituto de Hermenêutica Jurídica, v. 1, n. 4, 2006, p. 334. 
constitucionalidade. A fundamentação tem, portanto, duplo papel e dupla dimensão: (i) a racionalidade exclui a aplicação arbitraria ou manifestamente errônea da legalidade; (ii) o controle, que tem uma dimensão tanto interna, submetida, no seu caso, a tribunais superiores, quanto externa, voltada para as partes e para a comunidade. A partir do exposto, é possível afirmar que, do mesmo modo que há o deverfundamental de justificar/motivar as decisões, existe também o direito fundamental a obtenção derespostas corretas/adequadas a Constituição. Mais do que isso: a obtenção de respostas adequadasa Constituição implica o respeito à democracia. Trata-se de um direito (humano) fundamental docidadão. ${ }^{74}$

O juiz responsável é, nessa senda, aquele que se opõe ao juiz do sistema (que tem por missão declarar as injustiças da lei) e que compartilha do pensamento que recupera a função hermenêutica na compreensão de textos, sob o pressuposto epistemológico de que o texto carrega várias soluções jurídicas possíveis, já que texto e norma não são a mesma coisa. ${ }^{75}$ Aceitam-se, pois, respostas distintas em razão da problemática trazida pelo caso, mas buscam-se respostas corretas de acordo com a Constituição, já que se reconhece que a diferença pode levar a respostas diferentes. Sucede que a Constituição é o elo entre o direito e a política, garantindo, porquanto, a democracia. Assim, é necessário um mínimo conjunto hermenêutico de princípios que devem ser respeitados e seguidos pelo intérprete, sempre com base na historicidade da compreensão e na sedimentação dessa principiologia. Estes, contudo, somente se revelam no momento da aplicação interpretação do caso concreto, já que representam um contexto de significações históricas compartilhadas por determinada comunidade política.

\section{CONSIDERAÇÕES FINAIS}

Como restou evidenciado, no quadro inaugurado com a Constituição de 1988, a inércia do Executivo e a falta de atuação do Legislativo passaram a ser supridas pelo Judiciário.Essa possibilidade de atuação conferida no Estado Democrático de Direito não é, entretanto, discricionária, mas, sim, deve obedi-

74 Ou seja, o cidadão tem o direito a uma accountabillity hermenêutica. Há uma ligação umbilical entre esse dever fundamental e esse direito fundamental. A complementariedade entre ambos representa uma blindagem contra interpretações deslegitimadoras e despistadoras do conteúdo que sustenta o domínio normativo dos textos constitucionais. Trata-se de substituir qualquer pretensão solipsista pelas condições histórico-concretas, sempre lembrando, nesse contexto, a questão da tradição, da coerência e da integridade, para bem poder inserir a problemática na superação do esquema sujeito-objeto pela hermenêutica jurídico-filosófica (STRECK, Lenio Luiz. $\mathrm{O}$ direito de obter respostas constitucionalmente adequadas em tempos de crise do direito: a necessária concretização dos direitos humanos. Revista Latinoamericana de Derechos Humanos, v. 1, n. 1, julho/2010, p. 105).

${ }^{75}$ BAPTISTA DA SILVA, Ovídio. Jurisdição, Direito Material e Processo. Rio de Janeiro: Forense, 2008, p. 147-8. 
ência à compatibilidade com o sentido da Constituição, quem lhe outorgou essa legitimidade para agir.

O cavalo de Tróia da mitologia greco-romana tem muito a ensinar sobre issoQuase dez longos anos haviam se passado desde que principiara o cerco à cidade deTróia. Quando o ânimo de nossos homens chegava ao ponto mais baixo, Ulisses, ao observar a fogueira,ouviu o relincho isolado deum dos cavalos presos no redil ali próximo acordou os demais, fazendo com que todo oacampamento ressoasse com aquele atordoante concerto eqüino e teve a idéia: construir umimenso cavalo de madeira, um cavalo oco, onde estariam guardados homens, armados até os dentes, para quando o cavalo fosse introduzido dentro das muralhas da sagrada Tróia. E, de fato, isso se sucedeu. Localizado o monumento e acreditando que os aqueus tinham ido embora, Príamo, rei dos teucros, ordenou, então, que fosse o mesmo transportado para dentro das sólidas muralhas da cidade, pois caso os gregos resolvessem retornar com mais homens e novos engenhos de guerra, não teriam a proteção de Minerva, para quem acreditavam a construção fora feita. Uma maravilha, um presente digno dos deuses!exclamava o povo, ajuntado em frente e ao alto das muralhas, despedindo um grandegrito de espanto e admiração tão logo iam avistando-a. Entretanto, mal sabiam o que esse presente lhe reservava. As advertências de que o mesmo deveria ser queimado, pois ele seria a ruína, não foram ouvidas e ao cair na madrugada:

um rumor espantoso de armas e de gritos ergueu-se. Todos os homens arremessaram-se às portas escancaradas - que os homens de Ulisses já haviam aberto de par em par -, enquanto outra coluna gigantesca ia em direção à brecha da muralha, como uma onda negra e invencível que absolutamente nada poderia deter. Os soldados gregos entraram na cidade sem a menor cerimônia. Pequenos grupos de cem homens enveredaram em todas as direções, portando tochas, lanças e achas de dois gumes, prontos para abaterem qualquer coisa que quisesse lhes fazer frente. Os primeiros soldados troianos, pobres sentinelas abatidas pelo vinho, acordaram, ainda tontos, apenas para receberem em seus ventres o bronze afiado das espadas e das lanças inimigas. Outros, mais felizes, nem tinham tempo de acordar, sendo abatidos ainda deitados com o peso das achas que desabavam sobre seus corpos. As primeiras labaredas começaram a iluminar a noite, ofuscando a luz da lua. Pequenas casas e residências senhoris ardiam já incontrolavelmente. Homens deixavam as casas, sem saber direito o que estava ocorrendo, para serem abatidos impiedosamente, diante das esposas e dos filhos. ${ }^{76}$

Enéias, atendendo ao comando de sua mãe Vênus, vendo que naquele local a morte era soberana, colocou o velho pai sobre ascostas e pela outra mão conduziu seu pequenino Iulo em meios às labaredas dos incêndios:- Vá, não volte os olhos para trás, pois aqui não há mais nada a ser feito! — disse adeusa,

${ }^{76}$ FRANCHINI, A. S.; SEGANFREDO, Carmen. As 100 Melhores Histórias da Mitologia: deuses, heróis, monstros e guerras da tradição greco-romana. 9ª ed. Porto Alegre: L\&PM, 2007, p. 364. 
com ar severo. - O seu destino é reconstruir a sagrada Tróia em outras terras, muitodistantes daqui. Vá e cumpra sempre a sua missão.

Como ocorreu com a sagrada Tróia, vendo a destruição gerada no direito pelo apego ao paradigma da subjetividade, tem-se lutado incansavelmente(e aqui gostaria de ressaltar, em especial, o brilhante trabalho realizado em terra brasilis pelo jurista Lenio Luiz Streck) em efetuar uma crítica à discricionariedade e ao arbítrio, de modo que esse cavalo de Tróia da modernidade seja reconhecido antes que ocorra a degradação completa dos (pré)compromissos. Há, pois, de ser superada a cisão sujeito/objeto, tributária da filosofia da consciência. Toda decisão judicial está inevitavelmente mergulhada no mundo histórico, por isso a resposta correta deve obediência à tradição autêntica. $\mathrm{O}$ direito deve ser estudado como fato e não valor, como alude o paradigma positivista, retirando-lhe qualquer perspectiva transformadora, necessidade patente no bojo de uma Constituição compromissória. O direito não pode aprisionar o ente que lhe diz respeito como um objeto a ser dominado, medido e quantificado e que, uma vez delimitado, implica o permanente enquadramento de todo acontecimento futuro dentro dos seus moldes. Decisões constitucionalmente adequadas devem levar em conta a questão dacoerência, da integridade e o direito da parte de compreender os motivos que levaram o julgador a decidir contra ou a seu favor. A resposta correta, assim, evita decisões ad hoc,representando uma blindagem contra interpretações deslegitimadoras, o que, no bojo do cenário vivenciado na modernidade, se deve, cada vez mais, lutar, sob pena da democracia ser abatida impiedosamente, como os homens de Tróia.

\section{REFERÊNCIAS BIBLIOGRÁFICAS}

BAPTISTA DA SILVA, Ovídio. Fundamentação das sentenças como garantia constitucional. Revista do Instituto de Hermenêutica Jurídica, v. 1, n. 4, 2006.

. Jurisdição, Direito Material e Processo. Rio de Janeiro: Forense, 2008.

BONAVIDES, Paulo. Ciência Política. 10ª ed. São Paulo: Malheiros, 2000.

CANARIS, Claus-Wilhelm. Pensamento Sistemático e Conceito de Sistema na Ciência do Direito. Trad. A. Menezes Cordeiro. Lisboa: Fundação Calouste Gulbenkian, 1989.

CAPPELLETTI, Mauro. Juízes Legisladores? Trad. Carlos Alberto Alvaro de Oliveira. Porto Alegre: Sérgio Antonio Fabris, 1999.

DWORKIN, Ronald. Levando os Direitos a Sério. Trad. Nelson Boeira. São Paulo: Martins Fontes, 2002.

Fontes, 1999.

. O Império do Direito.Trad. Jeferson Luiz Camargo. São Paulo: Martins

. Uma Questão de Princípio. Trad. Luís Carlos Borges. São Paulo: Martins Fontes, 2001. 
GADAMER, Hans-Georg. Verdade e Método: traços fundamentais de uma hermenêutica filosófica. $2^{\text {a }}$ ed. Petrópolis: Vozes, 1998.

GIUSTI, Ernesto. Cardozo, Nathan Benjamin. In: BARRETTO, Vicente de Paulo (Coord.). Dicionário de Filosofia do Direito. São Leopoldo: UNISINOS, 2009.

GRAU, Eros Roberto. O Futuro do Direito. In: NUNES, António Joé Avelãs; COUTINHO, Jacinto Nelson de Miranda (Coord.). O Direito e o Futuro: o futuro do direito. Coimbra: Almedina, 2008.

GRONDIN, Jean. Introdução à Hermenêutica Filosófica. Trad. Benno Dischinger. São Leopoldo: UNISINOS, 1999.

HABERMAS, Jürgen. Between facts and norms: contributions to a discourse theory of law and democracy. Cambridge: MIT, 1996.

HECK, Philipp. Interpretação das Leis e Jurisprudência dos Interesses. Trad. José Osório. São Paulo: Saraiva, 1947.

HEIDEGGER, Martin. Ser e tempo. Vol. 1. 13ª ed. Petrópolis: Vozes, 2004.

KAUFMANN, Arthur; HASSEMER, Winfried (Org.). Introdução à Filosofia do Direito e à Teoria do Direito Contemporâneas. Trad. Marcos Keel e Manuel Seca de Oliveira. Lisboa: Fundação Calouste Gulbenkian, 2002.

LAMEGO, José. Hermenêutica e Jurisprudência: análise de uma recepção. Lisboa: Fragmentos, 1990.

LARENZ, Karl. Metodologia da Ciência do Direito. Trad. José Lamego. $3^{a}$ ed. Lisboa: Fundação Calouste Gulbenkian, 1997.

LOSANO, Mario G. Sistema e Estrutura do Direito: o século XX. Trad. Luca Lamberti. Vol. 2. São Paulo: Martins Fontes, 2010.

MORAIS, Jose Luis Bolzan de. Crises do estado, democracia política e possibilidades de consolidação da proposta constitucional. In: CANOTILHO, José Joaquim Gomes; STRECK, Lenio Luiz (Coord). Entre Discursos e Culturas Jurídicas. Coimbra: Coimbra, 2006.

NEVES, A. Castanheira. O Actual Problema Metodológico da Interpretação Jurídica.Coimbra: Coimbra, 2003.

STEIN, Ernildo. Aproximações sobre Hermenêutica. $2^{\mathrm{a}}$ ed. Porto Alegre: EDIPUC, 2004.

STRECK, Lenio Luiz. Aplicar a "letra da lei" é uma atitude positivista? Revista Novos Estudos Jurídicos, v. 15, n. 1, janeiro/abril 2010.

. Da "justeza dos nomes" à "justeza da resposta" constitucional. Revista do Instituto de Pesquisas e Estudos de Bauru, v. 43, n. 50, julho/dezembro 2008.

. Da Interpretação de Textos à Concretização de Direitos: a incindibilidade entre interpretar e aplicar a partir da diferença ontológica (ontologische differentz) 
entre texto e norma. In: COPETTI, André; STRECK, Lenio Luiz; ROCHA, Leonel Severo (Org.). Constituição, Sistemas Sociais e Hermenêutica. São Leopoldo: UNISINOS, 2005.

. Hermenêutica (jurídica): compreendemos porque interpretamos ou interpretamos porque compreendemos? Uma resposta a partir do Ontological Turn. In: ROCHA, Leonel Severo; STRECK, Lenio Luiz (Org.). Anuário do Programa de Pós-Graduação em Direito. São Leopoldo: UNISINOS, 2003.

. Hermenêutica Jurídica (e)m Crise: uma exploração hermenêutica da construção do Direito. Porto Alegre: Livraria do Advogado, 2011.

. Jurisdição Constitucional e Hermenêutica: Perspectivas e Possibilidades de Concretização dos Direitos Fundamentais-Sociais no Brasil. Revista Novos Estudos Jurídicos, v. 8, n. 2, maio/agosto 2003.

. O direito de obter respostas constitucionalmente adequadas em tempos de crise do direito: a necessária concretização dos direitos humanos. Revista Latinoamericana de Derechos Humanos, v. 1, n. 1, julho/2010

. O que é isto - decido conforme minha consciência? $2^{a}$ ed. Porto Alegre: Livraria do Advogado, 2010.

. Verdade e Consenso: Constituição, Hermenêutica e Teorias Discursivas - da possibilidade à necessidade de respostas corretas em Direito. $3^{3}$ ed. Rio de Janeiro: Lumen Juris, 2009.

; BARRETTO, Vicente de Paulo; OLIVEIRA, Rafael Tomaz de. Ulisses e o canto das sereias: sobre ativismos judiciais e os perigos da instauração de um "terceiro turno da constituinte". Revista de Estudos Constitucionais, Hermenêutica e Teoria do Direito, v. 1, n. 2, julho/dezembro 2009.

TRIBE, Laurence; DORF, Michael. Hermenêutica Constitucional. Trad. Amarílis de Souza Birchal. Belo Horizonte: Del Rey, 2007.

WALDRON, Jeremy. As intenções dos legisladores e a legislação não-intencional. In: MARMOR, Andrei (Org). Direito e Interpretação: ensaios de filosofia do direito. Trad. Luís Carlos Borges. São Paulo: Martins Fontes, 2000.

WARAT, Luis Alberto. Introdução Geral ao Direito III: o direito não estudado pela teoria jurídica moderna. Porto Alegre: Sergio Antonio Fabris, 1997. 